\title{
Anti-obesity effects of yellow catfish protein hydrolysate on mice fed a $45 \%$ kcal high-fat diet
}

\author{
MI-RYUNG KIM ${ }^{1 *}$, JOO-WAN KIM $^{2 *}$, JEONG BEEN PARK $^{1}$, \\ $\mathrm{YONG}^{\mathrm{KI} \mathrm{HONG}^{3}}{ }^{3}$, SAE KWANG KU ${ }^{4}$ and JAE-SUK CHOI ${ }^{1}$
}

\begin{abstract}
${ }^{1}$ Major in Food Biotechnology, Division of Bioindustry, College of Medical and Life Sciences, Silla University, Busan 46958; ${ }^{2}$ Aribio Inc., Byeoksan Digital Valley, Yeongdeungpo-gu, Seoul 07286; ${ }^{3}$ Department of Biotechnology, College of Fisheries Science, Pukyong National University, Busan 48513; ${ }^{4}$ Department of Anatomy and Histology, College of Oriental Medicine, Daegu Haany University, Gyeongsan-si, Gyeongsangbuk-do 38610, Republic of Korea
\end{abstract}

Received December 24, 2016; Accepted June 26, 2017

DOI: 10.3892/ijmm.2017.3063

\begin{abstract}
Obesity contributes to the etiologies of a variety of comorbid conditions, such as type 2 diabetes, hypertension and cardiovascular disease. In the present study, the anti-obesity effects of yellow catfish protein hydrolysate $(\mathrm{YPh})$ were observed in mice fed a 45\% kcal high-fat diet (HFD) compared with those of mice treated with simvastatin. The HFD-fed control mice exhibited noticeable increase in body weight, and whole-body and abdominal fat densities, periovarian and abdominal wall-deposited fat pad weight, as well as in the levels of triglycerides (TG), blood total cholesterol (TC), low-density lipoprotein, alanine aminotransferase, aspartate aminotransferase, creatinine, blood urea nitrogen, and in the fecal TG and TC contents. However, they exhibited a decrease in serum highdensity lipoprotein levels. In addition, an increase was detected in periovarian and dorsal abdominally deposited fat pad thickness, adipocyte hypertrophy, the number of steatohepatitis regions, hepatocyte hypertrophy and lipid droplet depositionrelated renal tubular vacuolation degenerative lesions, along with increased hepatic lipid peroxidation and a deteriorated endogenous antioxidant defense system (glutathione, catalase and superoxide dismutase). However, all the above-mentioned
\end{abstract}

Correspondence to: Professor Jae-Suk Choi, Major in Food Biotechnology, Division of Bioindustry, College of Medical and Life Sciences, Silla University, 140 Baegyang-daero 700 Beon-gil, Sasang-gu, Busan 46958, Republic of Korea

E-mail: jsc1008@silla.ac.kr

Professor Sae Kwang Ku, Department of Anatomy and Histology, College of Oriental Medicine, Daegu Haany University, 1 Hanuidae-ro, Gyeongsan-si, Gyeongsangbuk-do 38610, Republic of Korea

E-mail: gucci200@hanmail.net

*Contributed equally

Key words: anti-obesity effects, yellow catfish, protein hydrolysates, Pseudobagrus fulvidraco obesity-related complications were dose-dependently and significantly inhibited after 84 days of thye consecutive oral administration of 125,250 and $500 \mathrm{mg} / \mathrm{kg} \mathrm{YPh}$. In addition, YPh dose-dependently depleted the liver endogenous antioxidant defense system and inhibited hepatic lipid peroxidation. Overall, the effects of $250 \mathrm{mg} / \mathrm{kg}$ YPh on HFD-induced obesity and related complications were similar or more potent than those of $10 \mathrm{mg} / \mathrm{kg}$ simvastatin. These results indicate that $\mathrm{YPh}$ is a promising new potent medicinal ingredient for possible use in the treatment of obesity and related complications.

\section{Introduction}

Obesity contributes to the etiology of a variety of comorbid conditions, such as type 2 diabetes, hypertension and cardiovascular disease (1). Inflammation and metabolism in adipose and non-adipose tissues are affected by a variety of adipokines secreted by adipose tissues. Modulating the endocrine functions of adipose tissue contributes to chronic inflammation, which can cause associated disorders, specifically insulin resistance (2). The incidence of obesity associated with metabolic syndrome has increased worldwide and is likely the result of high-calorie diets and limited physical inactivity (3). Estimates suggest that this population may double to $>300$ million by the year 2025 (4). An increase in the regional distribution of body fat, i.e., abdominal obesity, can cause obesity (5). It results in the clustering of atherogenic risk factors, i.e., dyslipidemia, hypertension, inflammatory cytokine profiles, alterations in coagulation and hyperinsulinemic insulin resistance.

The morbidity and mortality rates from cardiovascular disease have increased (6). The accumulation of triglycerides (TGs) in many tissues is caused by the excessive intake of fatty acids, i.e., lipolysis caused by the accumulation of fat tissues. An increased circulation of fatty acids increases the risk of lipolysis in adipocytes and insulin resistance, resulting in a plethora of fatty acids stored in non-adipose tissues, such as the liver, pancreas and muscle. Increased levels of fatty acid binding and transport proteins in adipose and non-adipose tissues facilitate promote insulin resistance. The high availability of free fatty acids (FFAs) and their deposition in muscle induces a negative loop of insulin-mediated muscle insulin signaling and glucose 
utilization. The continued exposure of the pancreas to FFAs can impair insulin release through a lipotoxic mechanism (7). High FFA concentrations contribute to resistance to insulin action in the liver by enhancing hepatic glucose output (8). Non-alcoholic fatty liver disease (NAFLD) can be caused by the accumulation of TGs in the liver. NAFLD damages the liver, the main glucose metabolizing organ, and can cause hepatocellular necrosis steatosis, fibrosis and steatohepatitis (9). A balance between hepatic lipolysis and lipogenesis is important to prevent insulin resistance and NAFLD, which are characteristics of metabolic syndrome (10).

However, currently available pharmacological means for the treatment of metabolic syndrome have a number of limitations, i.e., high rates of secondary failure and adverse effects (11). Therefore, physicians are increasingly considering complementary and alternative approaches for patients with metabolic syndrome $(12,13)$.

Simvastatin is a lipid-lowering statins that inhibits HMG-CoA reductase $(14,15)$. Although simvastatin does not or only slightly increases blood insulin and glucose levels in animals and humans $(16,17)$, it has been used in the treatment of dyslipidemia and in the prevention of cardiovascular disease in patients with diabetes $(18,19)$ and has beens hown to exert favorable antioxidant effects on high-fat diet (HFD)-fed rats $(20,21)$. However, simvastatin can cause various side-effects, including joint pain, memory loss and myopathies $(22,23)$. Simvastatin $(10 \mathrm{mg} / \mathrm{kg})$ was selected as a reference drug in this study, at a dose level based on our previous HFD-fed mouse studies $(12,13)$.

Bioactive proteins are small amino acid sequences derived from food proteins having potential physiological properties (24). Fish hydrolysates are another beneficial protein supplement that is useful for the treatment of a variety of clinical conditions $(24,25)$. Fish hydrolysates have antiproliferative, anti-microbial and antioxidant effects (26). In particular, some protein hydrolysates have been shown to have anti-obesity and hypolipidemic effects in HFD-fed obese animals (27-30). The yellow(head) catfish or Korean bullhead (Tachysurus fulvidraco) is a bagrid catfish that inhabits Eastern Asia from Siberia to China, Korea, Vietnam and Laos, where it can be found in lakes and river channels. This catfish reaches a maximum weight of $3 \mathrm{~kg}$ and a length of $34.5 \mathrm{~cm}$, although it is much more commonly found in lengths of $8 \mathrm{~cm}$. It is a minor edible component in commercial fisheries $(31,32)$.

In the present study, we reported that yellow catfish protein hydrolysate (YPh) exerts anti-obesity effects, attenuating related complications in obese mice with mild diabetes fed a $45 \%$ kcal HFD (12,33-35).

\section{Materials and methods}

Animals and husbandry. Female specific pathogen-free ICR mice (age, 6 weeks at receipt; OrientBio, Seungnam, Korea) were used following a 7-day acclimatization period. The animals were allocated 4-5 per polycarbonate cage in a temperature $\left(20-25^{\circ} \mathrm{C}\right)$ - and humidity (40-45\%)-controlled room. The light:dark cycle was $12: 12 \mathrm{~h}$, and commercial rodent feed (Samyang Feed, Seoul, Korea) and water were supplied ad libitum. Animals that had completed a 1-week adaption period prior to being fed the HFD were allocated to 1 of 6 groups ( $n=8 /$ group, a total of 48 HFD-fed mice and normal diet fed mice) based on body weight (intact control: mean, 29.26 $1.95 \mathrm{~g}$; range, 26.00-32.20 g; HFD-fed group: mean, $32.07 \pm 1.45 \mathrm{~g}$; range, 29.70-35.80 g). All laboratory animals were treated according to the national regulations of the usage and welfare of laboratory animals, and approved by the Institutional Animal Care and Use Committee in Daegu Haany University (Gyeongsan, Gyeongbuk, Korea) (approval no. DHU2015-016).

Preparation and administration of test substances. The yellow catfish were kindly provided by an aquaculture farm (Gimje-si, Jeollabuk-do, Korea). They were placed in sterilized polyethylene bags (vacuum-packed; 450x650 mm) securely packed in polystyrene containers, and transported to Silla University (Busan, Korea) at $5^{\circ} \mathrm{C}$ using frozen ice packs within $4 \mathrm{~h}$. The light yellow-colored $\mathrm{YPh}$ powder was prepared as follows: briefly, fish tissues were warmed to $50^{\circ} \mathrm{C}$ for $10 \mathrm{~min}$, mixed with a 5-fold volume of distilled water, and reacted with Alcalase (E/S, 3.6 AU/g) at $50^{\circ} \mathrm{C}$ for $10 \mathrm{~min}$ (100 rpm shaking). The enzyme activities were then inhibited by heating in a water bath for $15 \mathrm{~min}$. Finally, the mixture was centrifuged at 4,000 rpm for $10 \mathrm{~min}$, and the supernatant was completely lyophilized. The $\mathrm{YPh}$ was stored at $-20^{\circ} \mathrm{C}$ to protect it from light and humidity until use. Simvastatin (Bicon Ltd., Bangalore, India) was used as a recommended reference drug. YPh (500, 250 and $125 \mathrm{mg} / \mathrm{kg}$ ) was dissolved in distilled water and orally administered once daily for 84 days beginning 7 days after the acclimatization to the HFD. Simvastatin $(10 \mathrm{mg} / \mathrm{kg})$ was also orally administered. Equal volumes of distilled water were orally administered to an intact vehicle and HFD-fed control mice (Fig. 1). The doses of YPh $(500,250$ and $125 \mathrm{mg} / \mathrm{kg}$ ) were selected based on in vivo efficacy tests of other protein hydrolysates in HFD-fed obese animals performed by other investigators (27-30).

$H F D$. The mice were adapted to the $45 \% / \mathrm{kcal}$ HFD (Research Diet, New Brunswick, NJ, USA) (Table I) for 7 days and fed this diet during the experiment. A normal pelleted diet (Superfeed Co., Seoul, Korea) was supplied to the intact controls.

Changes in body weight. Changes in the body weight of the mice were measured after 8 days (immediately before the commencement of the HFD feeding), 1 day prior to the administration of $\mathrm{YPh}$ and simvastatin $(10 \mathrm{mg} / \mathrm{kg})$, and weekly until termination using an automatic electronic balance (Precisa Instrument, Dietikon, Switzerland). All experimental animals were fasted overnight (no water for $12 \mathrm{~h}$ ) at the beginning and end of the feeding trial to reduce differences in the measured values from feeding. Body weight gain was calculated during the adoption (days 8-0 prior to the trial) and administration periods (days $0-84$ of the test substance administration), as described below in equation [1] and equation [2]:

Body weight gain (g) during the 7-day adaptation period $=$ [body weight at administration - body weight when fed the HFD (from 0-8 days before the test substance administration)] 
Table I. Formulas of normal and high-fat diets used in this study.

\begin{tabular}{lcc}
\hline Compositions & $\begin{array}{c}\text { Normal pellet diets } \\
(\mathrm{g} / \mathrm{kg} \text { diet })\end{array}$ & $\begin{array}{c}\text { High fat diets } \\
(\mathrm{g} / \mathrm{kg} \text { diet })^{\mathrm{a}}\end{array}$ \\
\hline Ingredient & & \\
Casein & 200 & 3 \\
L-Cystein & 3 & 72.8 \\
Corn starch & 150 & 172.8 \\
Sucrose & 500 & 50 \\
Cellulose & 50 & 25 \\
Soybean oil & 50 & 177.5 \\
Lard & 0 & 10 \\
Mineral mixture & 35 & 10 \\
Vitamin mixture & 10 & 2 \\
Choline bitartrate & 2 & 4.73 \\
Energy (kcal/g) & 0.21 & 20 \\
Protein $(\% \mathrm{kcal} / \mathrm{kg})$ & 13.3 & 35 \\
Carbohydrate $(\% \mathrm{kcal} / \mathrm{kg})$ & 47.4 & 45 \\
Fat $(\% \mathrm{kcal} / \mathrm{kg})$ & 8.0 & 8.0 \\
Fiber $(\% \mathrm{kcal} / \mathrm{kg})$ & 8.0 & \\
\hline
\end{tabular}

${ }^{\mathrm{a}} \mathrm{A} 45 \% \mathrm{kcal} / \mathrm{fat}$ pellet diet (D12451; Research Diet, New Brunswick, NJ, USA) was used as a high-fat diet (HFD) and a normal rodent pellet diet (Superfeed Co., Seoul, Korea) were used as a normal fat pellet diet.

Body weight gain $(\mathrm{g})$ during the 84-day administration period $=$ [body weight at termination - body weight at administration (from 0-84 days of the test article administration)] equation [2]

Mean daily food consumption. A $150 \mathrm{~g}$ food/cage was supplied and the quantity remaining in each cage was measured after $24 \mathrm{~h}$ using an automatic electronic balance. The individual mean daily food consumption by the mice (g/day/mice) was determined using equation [3] as follows:

Mean daily food consumption $(\mathrm{g} /$ day/mice $)=\frac{\begin{array}{c}\text { Quantity of diet supplied }(150 \mathrm{~g})- \\ \text { Quantity of remaining diet after } 24 \mathrm{~h}\end{array}}{\text { (Reared head of mice })}$

equation [3]

Measurements were taken once a week during the 84-day administration period.

Measurement of body fat density: Total and abdominal fat mass $(\%)$. Mean whole body and abdominal fat densities were measured in all mice using dual-energy X-ray absorptiometry (DXA; InAlyzer, Medikors, Seungnam, Korea) once after the 84-day test substance treatment was completed (Fig. 2).

Serum biochemistry. Blood was collected from the caudal vena cava after the 84 days of treatment, placed in clotting activated serum tubes, and centrifuged at $15,000 \mathrm{rpm}$ for $10 \mathrm{~min}$ at room temperature. The serum was collected for the later analyses of alanine aminotransferase (ALT), aspartate aminotransferase (AST), blood urea nitrogen (BUN), total

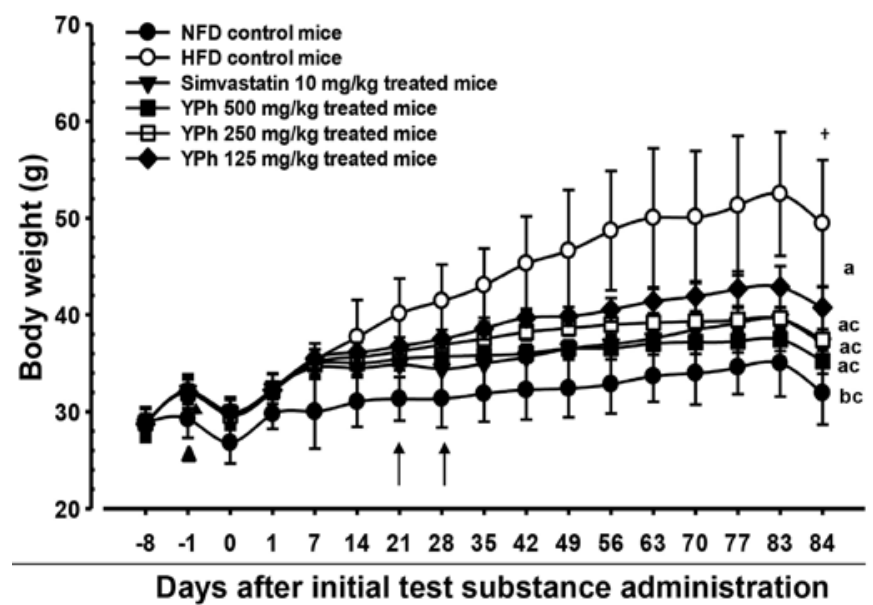

Figure 1. Body weight changes in NFD- or HFD-fed mice. HFD-fed control mice exhibited a significant $(\mathrm{p}<0.01)$ increase in body weight as compared with the intact mice from 1 week after the HFD supply (arrowhead). However, a significant $(\mathrm{p}<0.01$ or $\mathrm{p}<0.05)$ decrease in body weight was detected in the mice treated with simvastatin $10 \mathrm{mg} / \mathrm{kg}$, and $\mathrm{YPh} 500$ and $250 \mathrm{mg} / \mathrm{kg}$ from 21 days after the start of administration as compared with the HFD-fed controls (arrows). In addition, YPh the $125 \mathrm{mg} / \mathrm{kg}$-treated mice exhibited a significant $(\mathrm{p}<0.01$ or $\mathrm{p}<0.05)$ decrease in body weight from 28 days after the initial administration as compared with the HFD-fed control mice (arrows), in the present study. Values are expressed as the means \pm SD of 8 mice. NFD, normal fat pellet diet; HFD, 45\% kcal high fat diet; YPh, yellow(head) catfish or Korean bullhead (Tachysurus fulvidraco) protein hydrolysates, test material. Simvastatin was administrated at dose levels of $10 \mathrm{mg} / \mathrm{kg}$. All animals were fasted overnight before the initial test substance administration and sacrifice $(\dagger) .{ }^{a} \mathrm{p}<0.01$ and ${ }^{\mathrm{b}} \mathrm{p}<0.05$ as compared with the intact control as shown by the Mann-Whitney $U$ test; ${ }^{c} p<0.01$ as compared with the HFD-fed control as shown by the Mann-Whitney U test.

cholesterol (TC), creatinine, low-density lipoprotein (LDL), TG, high-density lipoprotein (HDL) and creatinine levels. Serum BUN, ALT, creatinine, AST, TG and TC levels were measured using an automated blood analyzer (Hemagen Analyst; Hemagen Diagnostic, Columbia, MD, USA) and serum LDL and HDL levels were detected using another type of automated blood analyzer (AU400; Olympus, Tokyo, Japan).

Measurement of organ weight. The weights of the pancreas, liver, left periovarian fat pads, left kidney and abdominal wall-deposited fat pads attached to the muscularis quadratus lumborum were measured individually at sacrifice at day 84 , and relative weights (\% body weight) were calculated using body weight at sacrifice and absolute weight to decrease differences among individual body weights.

Measurement offecal lipid composition. Lipids were extracted from feces collected after $8 \mathrm{~h}$ of the last test substance administration, according to the method of Folch et al (36). Fecal TG and TC concentrations were measured using a commercial enzyme kit (Asan Pharmaceutical Co., Seoul, Korea) based on a modification of the lipase-glycerol phosphate oxidase method (37-39).

Liver lipid peroxidation and antioxidant defense systems. The glutathione (GSH) and malondialdehyde (MDA) contents, as well as the superoxide dismutase (SOD) and catalase (CAT) activities, were assessed in mouse hepatic tissues. Separate 


\section{Gross image}

A
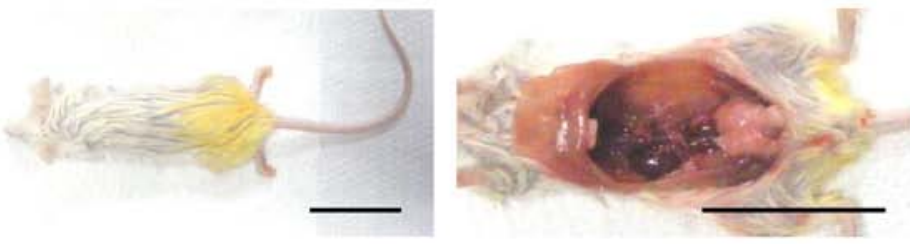

B

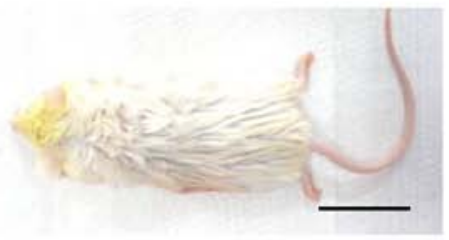

C

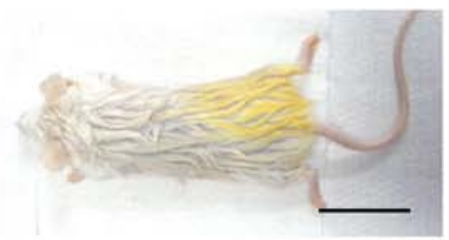

D

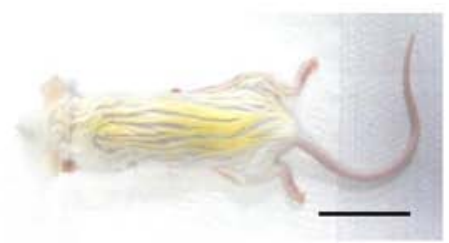

E

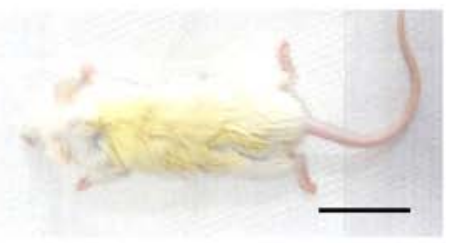

$\mathrm{F}$

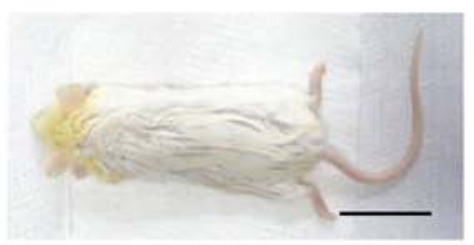

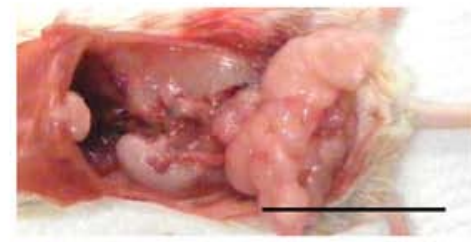
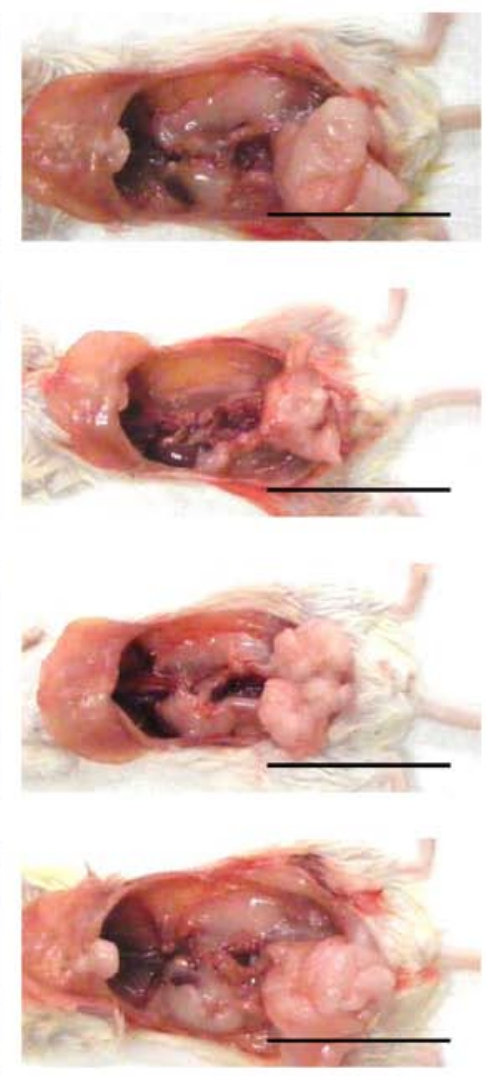

In live DXA image
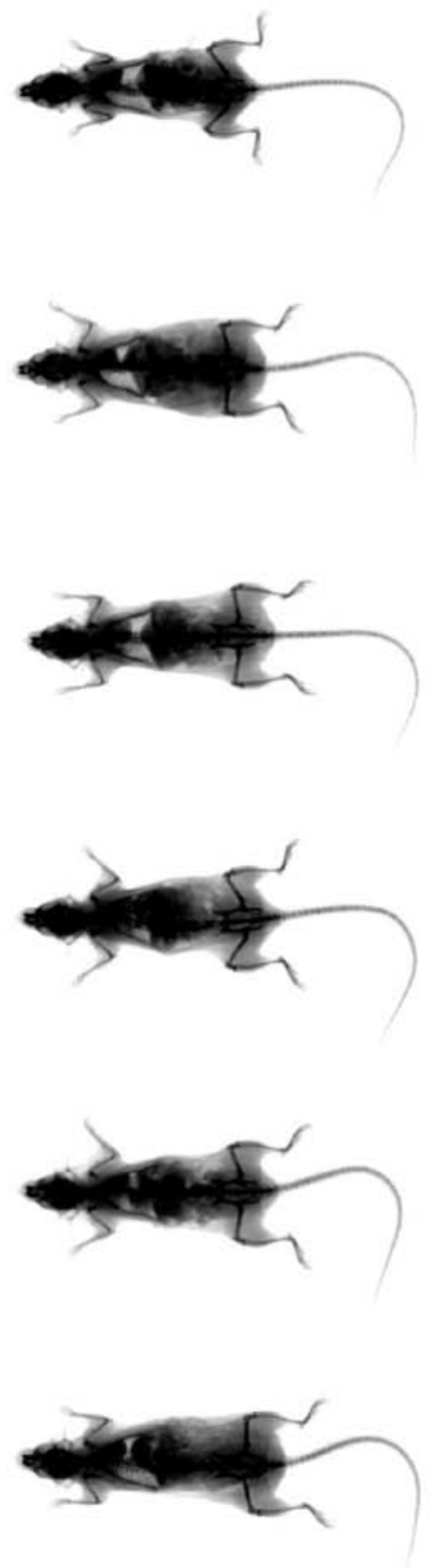

Figure 2. Representative gross body mass and abdominal fat pads with the whole body DXA images taken from NFD- or HFD-fed mice. HFD-induced obesity, led to a marked increase in body mass and related fat accumulation in the HFD-fed control mice as compared with the NFD-fed intact mice. However, a marked inhibition of body mass and fat deposition increase was detected in the mice treated with all test substances, including YPh $125 \mathrm{mg} / \mathrm{k}^{\mathrm{g}}$, at the analysis of gross inspections and in live DXA images, in our results. (A) Intact control: normal pellet diet-fed vehicle control mice; administered $10 \mathrm{ml} / \mathrm{kg}$ of distilled water orally. (B) HFD (vehicle) control, $10 \mathrm{ml} / \mathrm{kg}$ of distilled water administered orally with HFD supply. (C) Simvastatin, $10 \mathrm{mg} / \mathrm{kg}$ of simvastatin administered with HFD supply. (D) YPh 500, $500 \mathrm{mg} / \mathrm{kg}$ of YPh administered orally with HFD supply. (E) YPh 250, $250 \mathrm{mg} / \mathrm{kg}$ of YPh administered orally with HFD supply. (F) YPh 125, $125 \mathrm{mg} / \mathrm{kg}$ of YPh administered orally with HFD supply; NFD, normal fat pellet die; HFD, 45\% kcal high-fat diet; YPh, yellow(head) catfish or Korean bullhead (Tachysurus fulvidraco) protein hydrolysates, test material; DXA, dual-energy X-ray absorptiometry. Scale bar, 35 mm.

liver tissues were weighed and homogenized in ice-cold $0.01 \mathrm{M}$ Tris- $\mathrm{HCl}(\mathrm{pH} 7.4)$ and centrifuged at $12,000 \mathrm{x}$ for $15 \mathrm{~min}$ as previously described by Kavutcu et al (40). The degree of liver lipid peroxidation was measured by estimating the MDA content using the thiobarbituric acid test at an absorbance of $525 \mathrm{~nm}$ (nM MDA/mg tissue) (41). Total protein contents were measured using a previously reported method (42), with bovine serum albumin (Invitrogen, Carlsbad, CA, USA) as the internal standard. The homogenates were mixed with $0.1 \mathrm{ml}$ 25\% trichloroacetic acid (Merck, San Francisco, CA, USA) and centrifuged at 4,200 rpm for $40 \mathrm{~min}$ at $4^{\circ} \mathrm{C}$. The GSH contents were measured at an absorbance of $412 \mathrm{~nm}$ using 2-nitrobenzoic acid (Sigma-Aldrich, St. Louis, MO, USA) and reported as $\mu \mathrm{M} /$ mg tissue (43). The decomposition of $\mathrm{H}_{2} \mathrm{O}_{2}$ in the presence of CAT was monitored at $240 \mathrm{~nm}$ (44). CAT activity was defined as the amount of enzyme required to decompose $1 \mathrm{nM}$ of $\mathrm{H}_{2} \mathrm{O}_{2}$ 
per min at $25^{\circ} \mathrm{C}$ and $\mathrm{pH} 7.8$. The results were expressed as $\mathrm{U} /$ $\mathrm{mg}$ tissue. SOD activity was measured as previously described by Sun et al (45). SOD estimates were based on the generation of superoxide radicals produced by xanthine and xanthine oxidase, which react with nitro tetrazolium blue to form a blue formazan dye. SOD activity was measured at $560 \mathrm{~nm}$ based on the degree of inhibition of this reaction and was expressed as $\mathrm{U} / \mathrm{mg}$ tissue. One unit of SOD enzymatic activity was equal to the amount of enzyme that diminishes the initial absorbance of nitroblue tetrazolium by $50 \%$ over $1 \mathrm{~min}$.

Histopathological examination. The left kidney and the left lateral lobe of the liver, the left periovarian fat pads, the splenic lobe of the pancreas and the abdominal wall-deposited fat pads attached to the muscularis quadratus lumborum were fixed in $10 \%$ neutral buffered formalin. After embedding in paraffin, 3-4 $\mu \mathrm{m}$-thick serial sections were prepared and stained with hematoxylin and eosin (H\&E) for light microscopic examination. The histological profiles of individual organs were described. Portions of the liver that had been dehydrated in $30 \%$ sucrose were sectioned by cryostat for Oil Red O staining $(39,46)$. To observe more details of the histopathological changes, the steatohepatitis region and mean hepatocyte diameters (by H\&E staining) were calculated using an automated imaging analysis program (iSolution FL ver. 9.1; IMT $i$-Solution Inc., Vancouver, QC, Canada) according to previously reported methods $(12,13,39,46)$. The regions of steatohepatitis and percentage of fat-deposited regions in the hepatic parenchyma were calculated as percentages of lipid deposited regions ( $\% / \mathrm{mm}^{2}$ of hepatic parenchyma). The sections were cut using a cryostat, stained with Oil Red $\mathrm{O}$, and mean hepatocyte diameters were calculated using an automated image analysis process; at least 10 hepatocytes per liver field of view were considered. In addition, the mean number of lipid droplets deposited in vacuolated renal tubules was calculated using an automated image analysis process among 100 tubules (number/100 tubules in one field/sample). The mean diameter of white adipocytes in the fat pads was calculated using an automated image analysis process; at least 10 white adipocytes per fat pad were considered. Mean area occupied by zymogen granules $\left(\% / \mathrm{mm}^{2}\right.$ of pancreatic parenchyma), thicknesses of the periovarian and abdominal wall fat pad $(\mathrm{mm})$ deposits, diameters of pancreatic islets and number of pancreatic islets (islets $/ 10 \mathrm{~mm}^{2}$ of pancreatic parenchyma) were measured according to our previously established methods $(12,13,39)$. The histopathologist was blinded to the group distribution.

Immunohistochemistry. Other serially prepared sectioned pancreatic tissues were immunostained using the avidin-biotinperoxidase (ABC) method as previously described by Kang et al (39), with guinea pig polyclonal insulin (dilution $1: 2,000$ ) or rabbit polyclonal glucagon (dilution 1:2,000) (both from DiaSorin, Stillwater, MN, USA) antiserum. Briefly, endogenous peroxidase activity was blocked by incubation in methanol and $0.3 \% \mathrm{H}_{2} \mathrm{O}_{2}$ for $30 \mathrm{~min}$. Non-specific immunoglobulin binding was blocked with a normal horse serum blocking solution (dilution 1:100; Vector Laboratories, Burlingame, CA, USA) for $1 \mathrm{~h}$ in a humidity chamber. The primary antiserum was incubated overnight at $4^{\circ} \mathrm{C}$ in a humidity chamber and then incubated with the biotinylated universal secondary antibody (dilution 1:50; cat. no. PK-6200; Vectastain Elite $\mathrm{ABC}$ kit) and $\mathrm{ABC}$ reagents (Vectastain Elite $\mathrm{ABC}$ kit; dilution 1:50) (both from Vector Laboratories) for $1 \mathrm{~h}$ at room temperature in a humidity chamber. Finally, the tissues were subjected to a peroxidase substrate kit (Vector Laboratories) for $3 \mathrm{~min}$ at room temperature. All sections were rinsed 3 times between steps in $0.01 \mathrm{M}$ phosphate-buffered saline (PBS). Cells with $>20 \%$ immunoreactivity were regarded as positive compared with other naïve cells, and the mean numbers of insulin- and glucagon- immunoreactive cells dispersed in the pancreatic parenchyma were counted using an automated image analysis process, as previously described $(39,47)$ and the ratio was calculated using equation [4] as follows:

$$
\frac{\text { Insulin }}{\text { Glucagon }} \text { cells }(\text { ratio })=\frac{\text { Mean number of insulin }- \text { immunoreactive cells }}{\text { Mean number of glucagon immunoreactive cells }}
$$

equation [4]

Statistical analyses. All numerical values were expressed as the means \pm standard deviation of 8 mice. The results of the different dose groups were analyzed using a multiple comparison tests. The variance was examined using the Levene test (48). If the Levene test indicated no significant deviations from homogeneity, the data were analyzed by a one-way analysis of variance followed by a least significant difference (LSD) multi-comparison test to determine which pairs were significantly different. The non-parametric Kruskal-Wallis $\mathrm{H}$ test was conducted when the variance was heterogeneous as indicated by significant deviations from observed values on the Levene test. When a significant difference was observed in the Kruskal-Wallis $\mathrm{H}$ test, The Mann-Whitney U test was conducted to determine the specific pairs that were significantly different. Statistical analyses were conducted using SPSS version 14 (SPSS Inc., Chicago, IL, USA) (49). In addition, the percentage changes were calculated and compared with the HFD-fed control to examine the efficacy of the test substances, and the percentage changes between the intact and HFD-fed controls were calculated to observe disease, as described below using equations [5] and [6] according to our previous study (39).

$$
\begin{gathered}
\text { Percentage change compared with intact control }(\%)=\frac{\begin{array}{c}
\text { HFD control data - } \\
\text { Intact control data }
\end{array}}{\text { Intact control data }} \times 100 \\
\text { equation [5] } \\
\text { Percentage change compared with HFD control }(\%)=\frac{\begin{array}{c}
\text { Test substance } \\
\text { administered mice }
\end{array}}{\text { HFD control data }} \times 100 \\
\text { equation [6] }
\end{gathered}
$$

\section{Results}

\section{Effects on obesity}

Changes in body weight. The body weights of the HFD-fed control mice increased significantly $(\mathrm{p}<0.01)$ as compared with the intact mice (fed the normal diet) after 1 week. Accordingly, body weight gain increased significantly $(\mathrm{p}<0.01)$ from 7 days after adapting to the HFD through day 84 of administration compared with the intact control group. However, a 
Table II. Changes in body weight gain and mean daily food consumption in NFD- or HFD-fed mice.

\begin{tabular}{|c|c|c|c|c|c|c|}
\hline \multirow[b]{2}{*}{ Groups } & \multicolumn{4}{|c|}{ Body weight $(\mathrm{g})$ at days after initial test substance administration } & \multirow{2}{*}{$\begin{array}{l}\text { Body weight } \\
\text { gain during } \\
\text { administration } \\
\text { period [C-D] }\end{array}$} & \multirow[b]{2}{*}{$\begin{array}{l}\text { Mean daily food } \\
\text { consumption }(\mathrm{g})\end{array}$} \\
\hline & $\begin{array}{c}8 \text { days before } \\
{[\mathrm{A}]}\end{array}$ & $\begin{array}{c}1 \text { day before } \\
\text { [B] }\end{array}$ & $\begin{array}{l}0 \text { day }^{\mathrm{a}} \\
{[\mathrm{C}]}\end{array}$ & $\begin{array}{l}84 \text { days }^{\mathrm{a}} \\
{[\mathrm{D}]}\end{array}$ & & \\
\hline \multicolumn{7}{|l|}{ Controls } \\
\hline Intact & $28.83 \pm 1.65$ & $29.26 \pm 1.95$ & $26.79 \pm 2.13$ & $31.93 \pm 3.25$ & $5.14 \pm 1.76$ & $5.28 \pm 0.62$ \\
\hline HFD & $28.68 \pm 1.79$ & $32.08 \pm 1.79^{\mathrm{b}}$ & $29.84 \pm 1.69^{\mathrm{b}}$ & $49.44 \pm 6.59^{c}$ & $19.60 \pm 7.23^{\mathrm{c}}$ & $4.10 \pm 0.56^{c}$ \\
\hline \multicolumn{7}{|l|}{ Reference } \\
\hline Simvastatin & $28.74 \pm 1.30$ & $32.16 \pm 1.78^{b}$ & $29.95 \pm 2.11^{\mathrm{b}}$ & $37.06 \pm 1.69^{\mathrm{c}, \mathrm{e}}$ & $7.11 \pm 1.40^{\mathrm{d}, \mathrm{e}}$ & $4.08 \pm 0.40^{\mathrm{c}}$ \\
\hline \multicolumn{7}{|l|}{ YPh-treated } \\
\hline $500 \mathrm{mg} / \mathrm{kg}$ & $28.85 \pm 1.44$ & $31.98 \pm 1.60^{\mathrm{b}}$ & $29.88 \pm 1.59^{\mathrm{b}}$ & $35.21 \pm 1.29^{\mathrm{d}, \mathrm{e}}$ & $5.34 \pm 1.27^{\mathrm{e}}$ & $4.05 \pm 0.71^{\mathrm{c}}$ \\
\hline $250 \mathrm{mg} / \mathrm{kg}$ & $28.85 \pm 0.87$ & $31.94 \pm 0.88^{b}$ & $29.60 \pm 1.07^{\mathrm{b}}$ & $37.41 \pm 1.10^{\mathrm{c}, \mathrm{e}}$ & $7.81 \pm 1.34^{\mathrm{c}, \mathrm{e}}$ & $4.17 \pm 0.53^{c}$ \\
\hline $125 \mathrm{mg} / \mathrm{kg}$ & $28.75 \pm 1.04$ & $32.08 \pm 1.28^{\mathrm{b}}$ & $29.93 \pm 1.28^{\mathrm{b}}$ & $40.75 \pm 2.21^{\mathrm{c}, \mathrm{e}}$ & $10.83 \pm 2.24^{\mathrm{c}, \mathrm{e}}$ & $4.13 \pm 0.50^{c}$ \\
\hline
\end{tabular}

significant $(\mathrm{p}<0.01$ or $\mathrm{p}<0.05)$ decrease in body weight was detected in the $10 \mathrm{mg} / \mathrm{kg}$ simvastatin- and 500 and $250 \mathrm{mg} / \mathrm{kg}$ YPh-treated mice beginning at 21 days after the administration began compared with the HFD untreated control. Thus, the body weight gain during the 84-day administration period decreased significantly $(\mathrm{p}<0.01)$ in these groups compared with the HFD-fed control. In addition, the $125 \mathrm{mg} / \mathrm{kg}$ YPh-treated mice also lost a significant $(\mathrm{p}<0.01$ or $\mathrm{p}<0.05)$ amount of body weight beginning 28 days after the initial administration and experienced a significant $(\mathrm{p}<0.01)$ decrease in body weight gain during the 84-day administration period, compared with HFD-fed control mice (Fig. 1 and Table II).

Effects on food consumption. Mean daily food consumption decreased significantly $(\mathrm{p}<0.01)$ in all HFD-fed mice compared with the intact control; however, no changes in mean daily food consumption were detected in any of the test substance-administered groups compared with the HFD-fed control (Table II).

Effects on body fat density: total and abdominal fat mass (\%). Total body and abdominal fat density increased significantly $(\mathrm{p}<0.01)$ in the HFD-fed control compared with the intact control groups. By contrast, total body and abdominal fat mass decreased significantly $(\mathrm{p}<0.01)$ in the $10 \mathrm{mg} / \mathrm{kg}$ simvastatin- and YPh, 125, 250 and $500 \mathrm{mg} / \mathrm{kg}$-treated mice compared with the HFD-fed control mice according to the DXA results (Figs. 2 and 3).

Effects on periovarian-deposited fat pad weight. Periovarian-deposited fat pad weight increased significantly $(\mathrm{p}<0.01)$ in the HFD-fed control group compared with the intact control group. However, the increase $(\mathrm{p}<0.01)$ in absolute and relative weight decreased significantly in response to all test substances, including $500 \mathrm{mg} / \mathrm{kg}$ YPh (Table III and Fig. 2).

Effects on abdominal wall-deposited fat pad weight. The absolute and relative weight of the abdominal wall-deposited fat pads increased significantly $(\mathrm{p}<0.01)$ in the HFD-fed control mice compared with the intact controls. However, the increase in abdominal wall-deposited fat pad weight decreased significantly $(\mathrm{p}<0.01)$ in response to all test substances (Table III and Fig. 2).

Effects on adipocyte histopathology in periovarian-and abdominal wall-deposited fat pads. Periovarian and abdominal white adipocyte diameters and fat pad thickness increased significantly $(\mathrm{p}<0.01)$ in the HFD-fed control mice compared with the intact controls. However, adipocyte hypertrophy and the fat deposits were significantly $(\mathrm{p}<0.01)$ inhibited by all test substances, including $10 \mathrm{mg} / \mathrm{kg}$ simvastatin, compared to the HFD-fed control group (Table IV and Fig. 4).

\section{Effects on the pancreas}

Effects on pancreatic weight. Relative pancreatic weight decreased significantly $(\mathrm{p}<0.01)$ in the HFD-fed control mice compared with the intact control mice; however, relative pancreatic weight increased significantly $(\mathrm{p}<0.01)$ in the mice treated with $10 \mathrm{mg} / \mathrm{kg}$ simvastatin and 500,250 and $125 \mathrm{mg} / \mathrm{kg}$ YPh compared with the HFD-fed control mice. No changes in absolute pancreatic weight were detected in any of the experimental HFD-fed mice, including the control mice compared with the intact controls (Table III).

Effects on exocrine pancreas zymogen granule content. The exocrine pancreas zymogen granule content decreased significantly $(\mathrm{p}<0.01)$ in the HFD-fed controls compared with the intact controls fed the NFD, resulting from the release of zymogen granules. However, the exocrine pancreas zymogen granule content increased significantly $(\mathrm{p}<0.01)$ in all test drug-treated mice compared to the HFD-fed control, apart from the $10 \mathrm{mg} / \mathrm{kg}$ simvastatin-treated mice, in which the percentage of exocrine pancreas occupied by zymogen granules only increased slightly compared to the HFD-fed control mice (Table V and Fig. 5). 


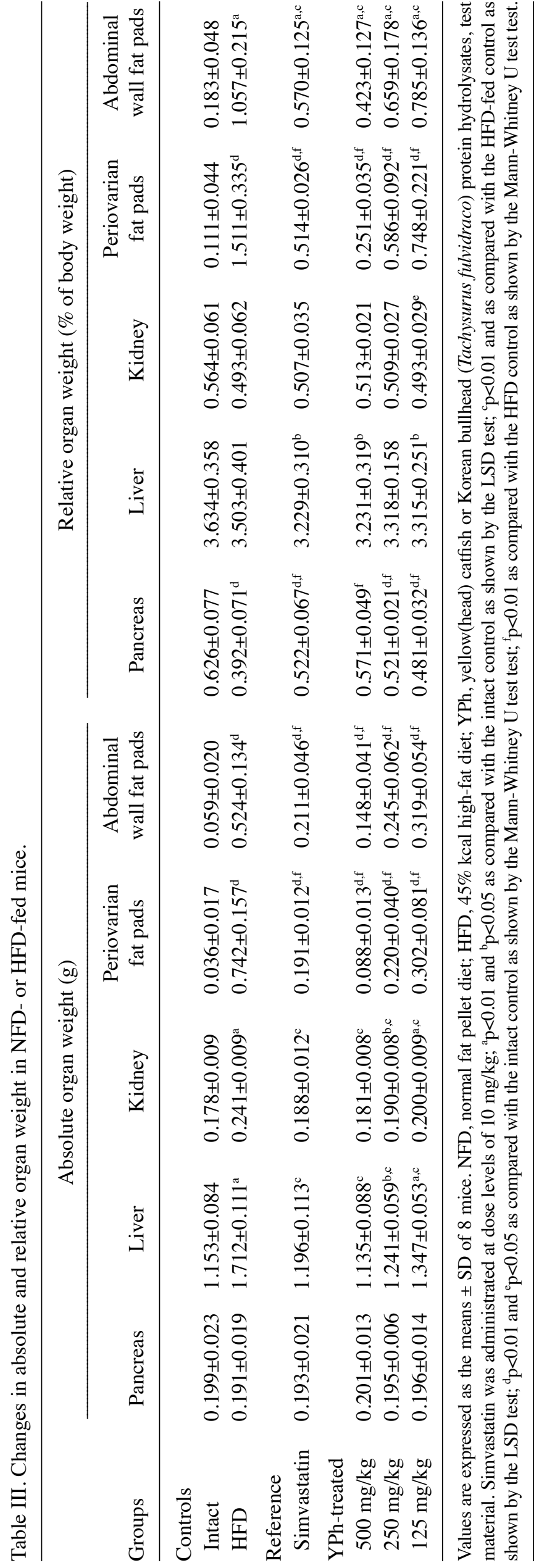

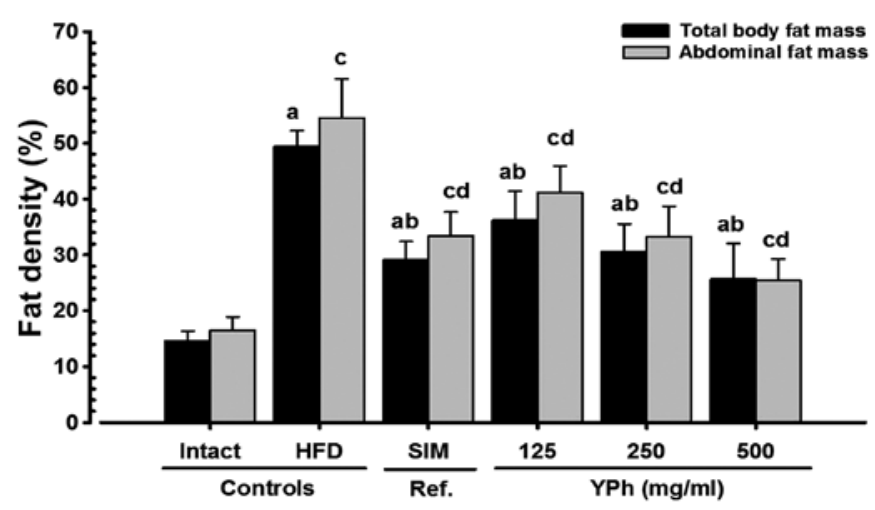

Figure 3. Total body and abdominal fat densities in NFD- or HFD-fed mice. A significant $(\mathrm{p}<0.01)$ increase in total body and abdominal fat density was detected in the HFD-fed controls as compared with the intact controls. On the contrary, a significant $(\mathrm{p}<0.01)$ decrease in total body and abdominal fat mass was detected in the mice treated with simvastatin $10 \mathrm{mg} / \mathrm{kg}$, and $\mathrm{YPh} 500,250$ and $125 \mathrm{mg} / \mathrm{kg}$ as compared with the HFD-fed control mice, at the analysis by DXA. Values are expressed as the means \pm SD of 8 mice. NFD, normal fat pellet die; HFD, 45\% kcal high-fat diet; SIM, simvastatin; YPh, yellow(head) catfish or Korean bullhead (Tachysurus fulvidraco) protein hydrolysates, test material; DXA, dual-energy X-ray absorptiometry. Simvastatin (SIM) was administrated at dose levels of $10 \mathrm{mg} / \mathrm{k}^{\mathrm{g}} .{ }^{\mathrm{a}} \mathrm{p}<0.01$ as compared with the intact control as shown by the LSD test; ${ }^{b} \mathrm{p}<0.01$ as compared with the HFD-fed control as shown by the LSD test; ${ }^{c} p<0.01$ as compared with the intact control as shown by the Mann-Whitney U test; ${ }^{\mathrm{d}} \mathrm{p}<0.01$ as compared with the HFD control as shown by the Mann-Whitney U test.

\section{Effects on hyperlipidemia}

Effects on serum TC levels. A significant $(\mathrm{p}<0.01)$ increase in serum TC levels was detected in the HFD-fed controls compared to the intact controls. However, the serum TC levels decreased significantly $(\mathrm{p}<0.01)$ in all the test substance-treated groups, including the mice treated with $500 \mathrm{mg} / \mathrm{kg} \mathrm{YPh}$, compared to the HFD-fed controls (Table VI).

Effects on serum TG levels. A significant $(\mathrm{p}<0.01)$ increase in serum TG levels was detected in the HFD-fed controls compared to the intact controls. However, the serum TG levels decreased significantly $(\mathrm{p}<0.01)$ in all of the test substancetreated groups, including the $250 \mathrm{mg} / \mathrm{kg} \mathrm{YPh}$-treated mice, compared to the HFD-fed controls (Table VI).

Effects on serum LDL levels. A significant $(\mathrm{p}<0.01)$ increase in serum LDL levels was observed in the HFD-fed controls compared to the intact controls. However, the serum LDL levels decreased significantly $(\mathrm{p}<0.01)$ in all the test substance-treated mice, including the mice that received $10 \mathrm{mg} / \mathrm{kg}$ simvastatin compared to the HFD-fed controls (Table VI).

Effects on serum HDL levels. A significant $(\mathrm{p}<0.01)$ decrease in serum HDL levels was detected in the HFD-fed controls compared to the intact controls. However, the serum HDL levels increased significantly $(\mathrm{p}<0.01)$ in all test substance-treated HFD-fed mice compared with the HFD-fed control mice (Table VI).

Effects on fecal TG and TC contents. Although a slight increase in the fecal TG and TC contents was detected in the HFD-fed controls compared with the intact controls fed the NFD, the fecal TG and TC contents in all the test substancetreated mice, including those treated with $500 \mathrm{mg} / \mathrm{kg} \mathrm{YPh}$, increased significantly $(\mathrm{p}<0.01)$ compared to HFD-fed control mice (Fig. 6). 


\section{Periovarian-deposited fat pads}

A

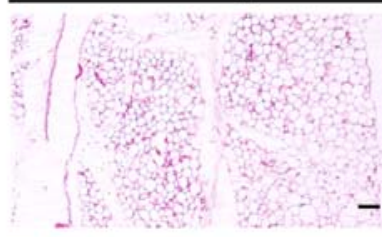

B

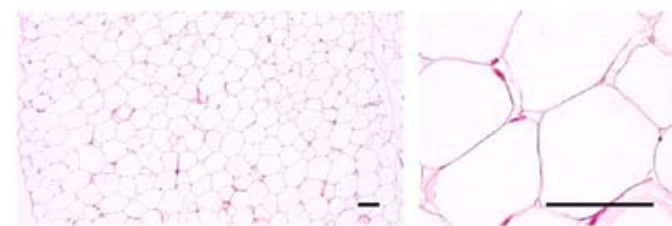

C

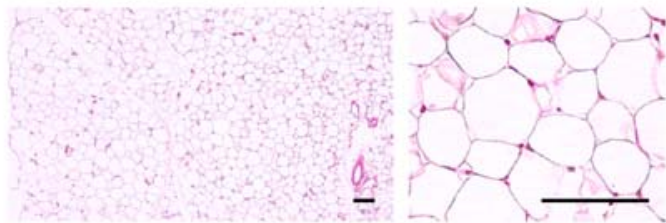

D

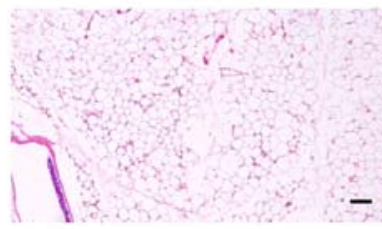

E
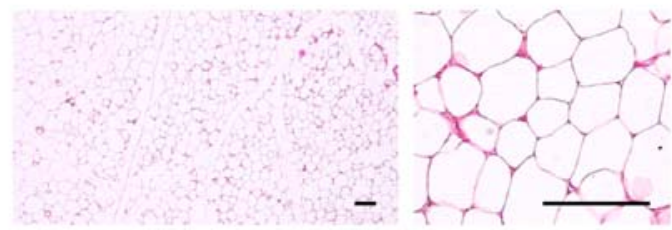

$\mathrm{F}$
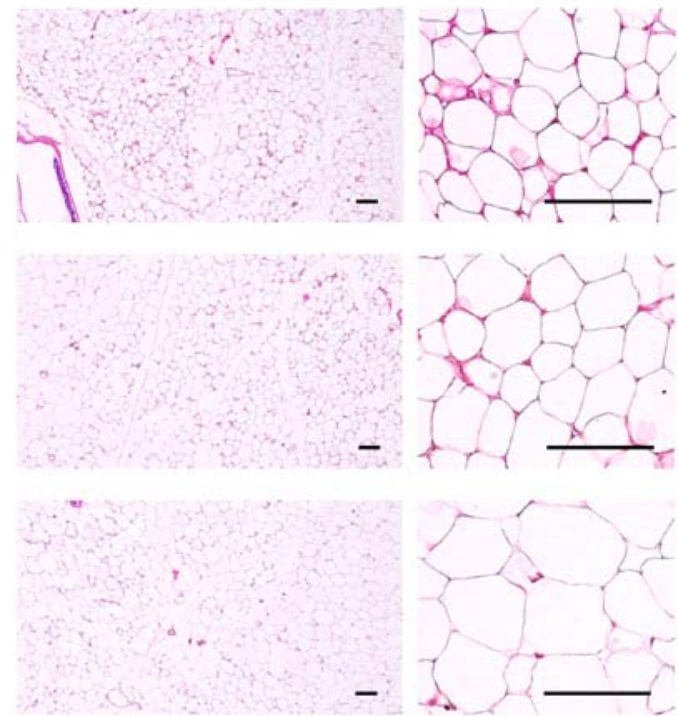

\section{Abdominal wall-deposited fat pads}
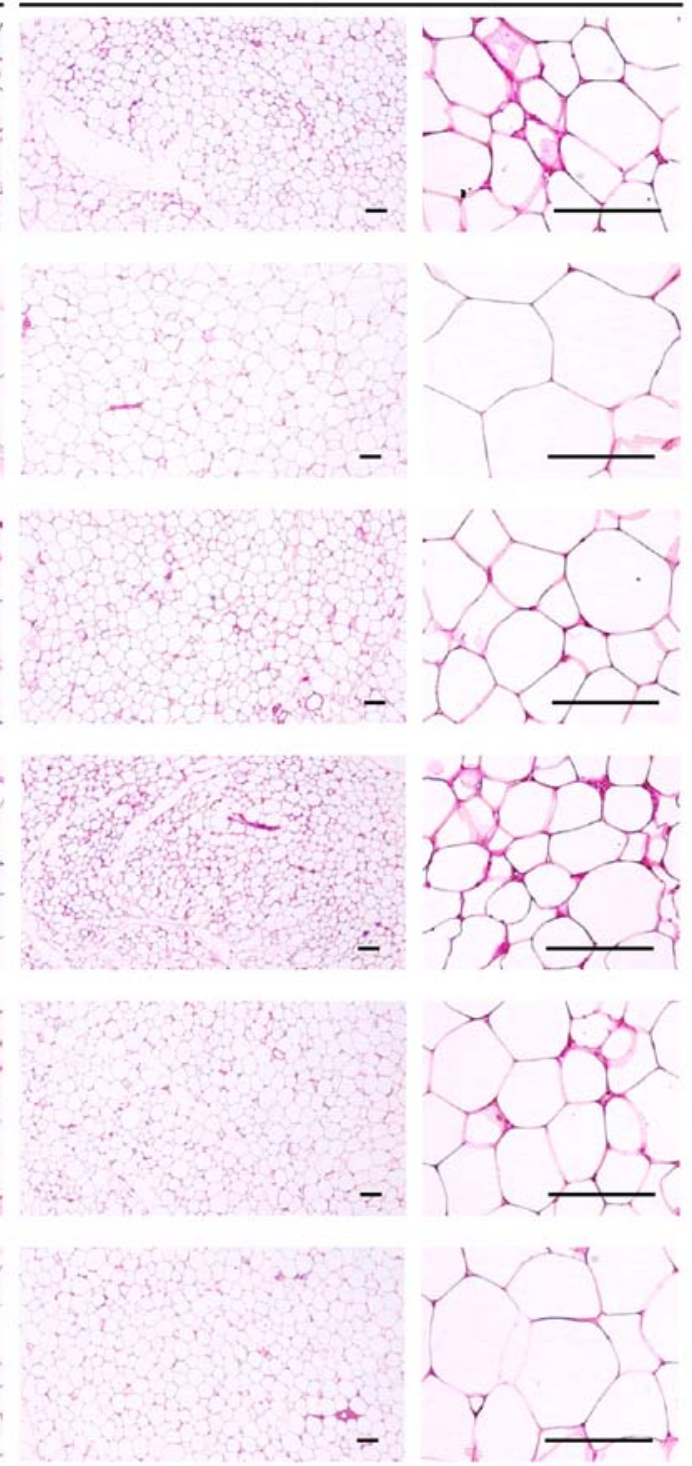

Figure 4. Representative histological images of the adipocytes, taken from NFD- or HFD-fed mice; the periovarian- and abdominal wall-deposited fat pads are shown. A significant increase in periovarian and abdominal white adipocyte diameters and thickness of each deposited fat pads was detected in the HFD-fed controls as compared with the intact controls. However, these hypertrophic changes in adipocytes and fat depositions were significantly inhibited by treatment with all test substances as compared with the HFD-fed controls. (A) Intact control: normal pellet diet-fed vehicle control mice; administered 10 ml/kg of distilled water orally. (B) HFD (vehicle) control, $10 \mathrm{ml} / \mathrm{kg}$ of distilled water administered orally with HFD supply. (C) Simvastatin, $10 \mathrm{mg} / \mathrm{kg}$ of simvastatin administered with HFD supply. (D) YPh 500, $500 \mathrm{mg} / \mathrm{kg}$ of YPh administered orally with HFD supply. (E) YPh 250, $250 \mathrm{mg} / \mathrm{kg}$ of YPh administered orally with HFD supply. (F) YPh 125, $125 \mathrm{mg} / \mathrm{kg}$ of YPh administered orally with HFD supply; NFD, normal fat pellet die; HFD, 45\% kcal high-fat diet; YPh, yellow(head) catfish or Korean bullhead (Tachysurus fulvidraco) protein hydrolysates, test material. All images show hematoxylin and eosin staining. Scale bars, $80 \mu \mathrm{m}$.

\section{Effects on hepatopathy}

Effects on liver weight. A significant $(\mathrm{p}<0.01)$ increase in absolute liver weight was detected in the HFD-fed controls compared to the intact controls. However, this increase was significantly $(\mathrm{p}<0.01)$ normalized by treatment with all the test substances compared to the HFD-fed control mice. No changes in relative liver weight were observed in the HFD-fed control mice compared to the intact control mice, and no changes in relative liver weight were observed in any of the test substance-treated mice compared with the HFD-fed control mice (Table III).

Effects on serum AST levels. A significant $(\mathrm{p}<0.01)$ increase in serum AST levels was detected in the HFD-fed controls compared with the intact controls. However, the serum AST levels decreased significantly $(\mathrm{p}<0.01)$ in all the test substancetreated mice compared with the HFD-fed controls (Table VII).

Effects on serum ALT levels. A significant $(\mathrm{p}<0.01)$ increase in the serum ALT levels was detected in the HFD-fed controls compared with the intact controls. However, the serum ALT levels decreased significantly $(p<0.01)$ in all the test substance-treated mice, including those treated with $10 \mathrm{mg} / \mathrm{kg}$ simvastatin, compared with the HFD-fed controls (Table VII).

Effects on steatohepatitis. A significant $(\mathrm{p}<0.01)$ increase in steatohepatitis (percentage of fat-affected regions in the liver parenchyma) was detected in the HFD-fed controls compared with the intact controls, resulting from the severe hypertrophy of hepatocytes related to intracellular lipid deposition. However, steatohepatitis was significantly $(\mathrm{p}<0.01)$ 
Table IV. Changes in the histopathology-histomorphometry of the periovarian- and abdominal wall-deposited fat pads in NFD- or HFD-fed mice.

\begin{tabular}{|c|c|c|c|c|}
\hline \multirow[b]{2}{*}{ Groups } & \multicolumn{2}{|c|}{ Periovarian fat pads } & \multicolumn{2}{|c|}{ Abdominal wall fat pads } \\
\hline & $\begin{array}{l}\text { Thickness } \\
\text { (mm) }\end{array}$ & $\begin{array}{l}\text { Adipocyte diameters } \\
\qquad(\mu \mathrm{m})\end{array}$ & Thickness & $\begin{array}{l}\text { Adipocyte diameters } \\
\qquad(\mu \mathrm{m})\end{array}$ \\
\hline \multicolumn{5}{|l|}{ Controls } \\
\hline Intact & $1.60 \pm 0.54$ & $36.46 \pm 11.29$ & $1.99 \pm 0.35$ & $44.02 \pm 12.37$ \\
\hline HFD & $5.57 \pm 1.00^{\mathrm{a}}$ & $131.14 \pm 24.68^{c}$ & $6.21 \pm 0.74^{\mathrm{c}}$ & $126.26 \pm 18.18^{\mathrm{a}}$ \\
\hline \multicolumn{5}{|l|}{ Reference } \\
\hline Simvastatin & $2.81 \pm 0.59^{\mathrm{a}, \mathrm{b}}$ & $54.42 \pm 12.72^{\mathrm{d}, \mathrm{e}}$ & $2.89 \pm 0.59^{\mathrm{c}, \mathrm{e}}$ & $64.60 \pm 15.07^{\mathrm{a}, \mathrm{b}}$ \\
\hline \multicolumn{5}{|l|}{ YPh-treated } \\
\hline $500 \mathrm{mg} / \mathrm{kg}$ & $2.56 \pm 0.45^{\mathrm{a}, \mathrm{b}}$ & $51.08 \pm 7.28^{\mathrm{d}, \mathrm{e}}$ & $2.49 \pm 0.46^{\mathrm{c}, \mathrm{e}}$ & $50.21 \pm 9.17^{\mathrm{b}}$ \\
\hline $250 \mathrm{mg} / \mathrm{kg}$ & $3.08 \pm 0.50^{\mathrm{a}, \mathrm{b}}$ & $60.05 \pm 7.46^{\mathrm{c}, \mathrm{e}}$ & $3.12 \pm 0.31^{\mathrm{c}, \mathrm{e}}$ & $68.10 \pm 10.28^{\mathrm{a}, \mathrm{b}}$ \\
\hline $125 \mathrm{mg} / \mathrm{kg}$ & $3.81 \pm 0.79^{\mathrm{a}, \mathrm{b}}$ & $77.72 \pm 19.23^{\mathrm{c}, \mathrm{e}}$ & $4.71 \pm 0.80^{\mathrm{c}, \mathrm{e}}$ & $87.73 \pm 14.28^{\mathrm{a}, \mathrm{b}}$ \\
\hline
\end{tabular}

Table V. Changes in histopathology-histomorphometry of the pancreas, liver and kidneys in the NFD-fed or HFD-fed mice.

\begin{tabular}{|c|c|c|c|c|}
\hline Groups & $\begin{array}{l}\text { Zymogen granules } \\
\left(\% / \mathrm{mm}^{2} \text { of exocrine }\right)\end{array}$ & $\begin{array}{c}\text { Liver steatosis }\left(\% / \mathrm{mm}^{2}\right. \\
\text { of hepatic tissues) }\end{array}$ & $\begin{array}{c}\text { Mean hepatocyte } \\
\text { diameters }(\mu \mathrm{m} / \text { cell })\end{array}$ & $\begin{array}{l}\text { Degenerative renal } \\
\text { tubule numbers }(\%)\end{array}$ \\
\hline \multicolumn{5}{|l|}{ Controls } \\
\hline Intact & $53.64 \pm 10.09$ & $7.27 \pm 2.36$ & $17.72 \pm 1.91$ & $3.13 \pm 1.64$ \\
\hline HFD & $13.46 \pm 3.28^{\mathrm{c}}$ & $76.36 \pm 9.61^{\mathrm{a}}$ & $53.45 \pm 12.48^{a}$ & $73.88 \pm 14.66^{a}$ \\
\hline \multicolumn{5}{|l|}{ Reference } \\
\hline Simvastatin & $16.23 \pm 5.42^{\mathrm{c}}$ & $32.45 \pm 10.25^{\mathrm{a}, \mathrm{b}}$ & $22.46 \pm 3.28^{\mathrm{a}, \mathrm{b}}$ & $35.75 \pm 14.44^{\mathrm{a}, \mathrm{b}}$ \\
\hline \multicolumn{5}{|l|}{ YPh-treated } \\
\hline $500 \mathrm{mg} / \mathrm{kg}$ & $43.90 \pm 6.85^{\mathrm{d}, \mathrm{e}}$ & $19.95 \pm 4.89^{\mathrm{a}, \mathrm{b}}$ & $21.29 \pm 2.36^{\mathrm{a}, \mathrm{b}}$ & $19.00 \pm 7.6^{5 \mathrm{a}, \mathrm{b}}$ \\
\hline $250 \mathrm{mg} / \mathrm{kg}$ & $36.69 \pm 5.93^{\mathrm{c}, \mathrm{e}}$ & $31.99 \pm 10.05^{\mathrm{a}, \mathrm{b}}$ & $25.79 \pm 3.75^{\mathrm{a}, \mathrm{b}}$ & $39.25 \pm 11.62^{\mathrm{a}, \mathrm{b}}$ \\
\hline $125 \mathrm{mg} / \mathrm{kg}$ & $29.91 \pm 7.28^{\mathrm{c}, \mathrm{e}}$ & $50.50 \pm 11.60^{\mathrm{a}, \mathrm{b}}$ & $32.36 \pm 6.36^{\mathrm{a}, \mathrm{b}}$ & $44.38 \pm 12.15^{\mathrm{a}, \mathrm{b}}$ \\
\hline
\end{tabular}

Values are expressed as the means \pm SD of 8 mice. NFD, normal fat pellet diet; HFD, 45\% kcal high-fat diet; YPh, yellow(head) catfish or Korean bullhead (Tachysurus fulvidraco) protein hydrolysates, test material. Simvastatin was administrated at dose levels of $10 \mathrm{mg} / \mathrm{kg}$. ${ }^{\mathrm{p}} \mathrm{p}<0.01$ as compared with the intact controls as shown by the Mann-Whitney U test test; ${ }^{b} \mathrm{p}<0.01$ as compared with the HFD-fed controls as shown by the Mann-Whitney U test test.

normalized following treatment of the mice with the test substances (Table V and Fig. 7).

Effects on hepatocyte hypertrophy. A significant $(\mathrm{p}<0.01)$ increase in mean hepatocyte diameter (hypertrophy) was detected in the HFD-fed controls compared with the intact controls. However, hypertrophy decreased significantly $(\mathrm{p}<0.01)$ in all test substance-treated mice compared with the HFD-fed controls (Table V and Fig. 7).

\section{Effects on nephropathy}

Effects on kidney weight. A significant $(\mathrm{p}<0.01)$ increase in absolute kidney weight was detected in the HFD-fed control mice compared with the intact controls; however, these effects were significantly $(\mathrm{p}<0.01)$ normalized following treatment with all of the substances compared to HFD-fed mice. No changes in relative kidney weight were observed in the HFD-fed control mice compared with the intact control mice, and no changes in relative kidney weight were observed in any of the test substance-treated mice compared with the HFD-fed control mice (Table III).

Effects on serum BUN levels. A significant $(\mathrm{p}<0.01)$ increase in serum BUN levels was detected in the HFD-fed controls compared with the intact controls fed the NFD. However, the serum BUN levels decreased significantly $(\mathrm{p}<0.01)$ in 

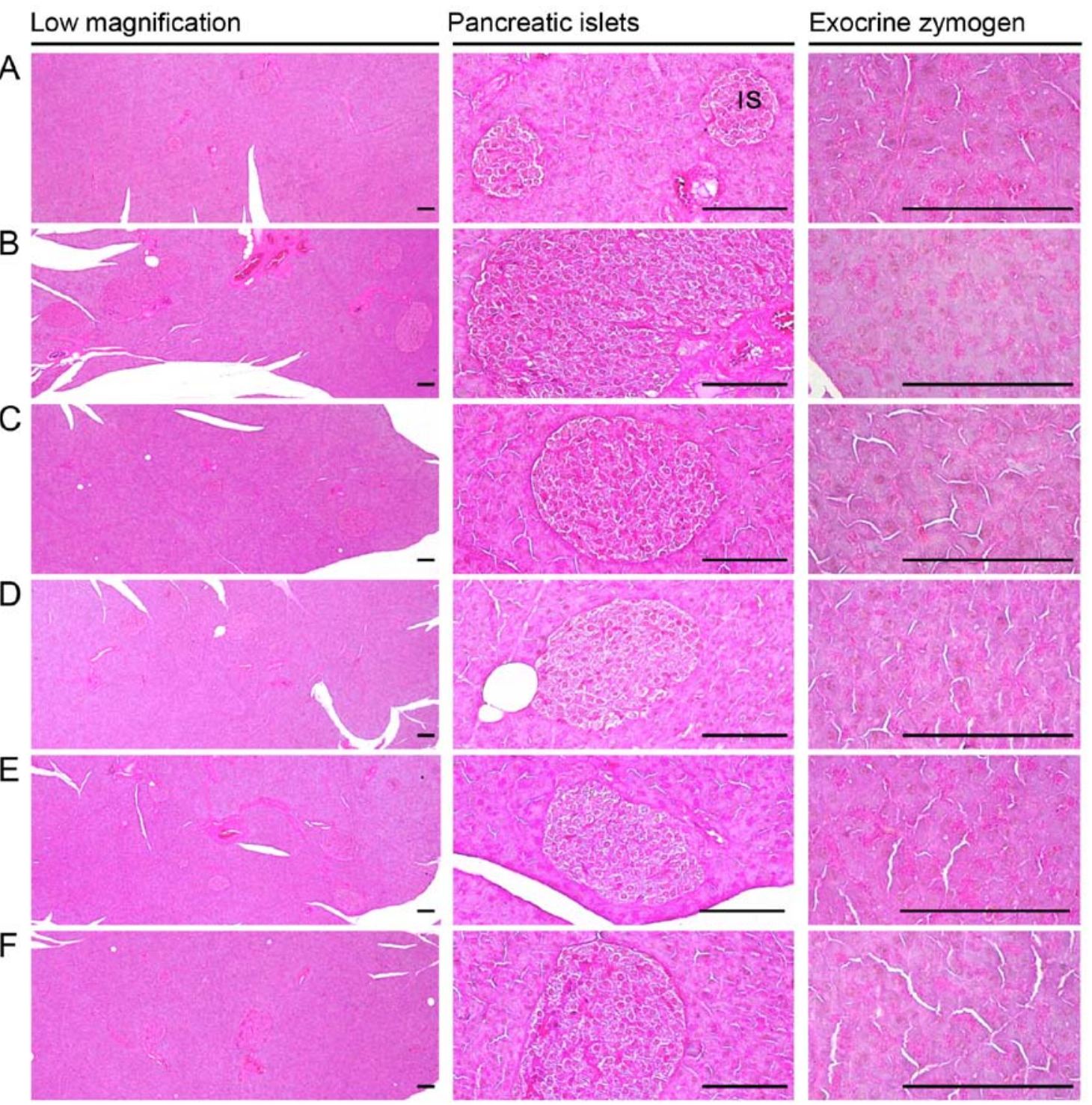

Figure 5. Representative general histological images of the pancreas, taken from NFD- or HFD-fed mice. Note that a marked decrease in exocrine pancreas zymogen granule contents (the percentages of exocrine pancreas occupied by zymogen granules) may be the result of the release of zymogen granules, and the increase in pancreatic islet numbers and mean diameters results from marked hyperplasia of the pancreatic islet itself or component endocrine cells that were detected in the HFD-fed controls as compared with intact controls. However, exocrine pancreas zymogen granule contents were markedly increased in the mice treated with all test substances as compared with the HFD-fed controls, apart from the simvastatin $10 \mathrm{mg} / \mathrm{kg}$-treated mice, in which the percentages of exocrine pancreas occupied by zymogen granules were non-significantly altered as compared to those of the HFD-fed control mice. In addition, the expansion of pancreatic islets was also inhibited by treatment with all test substances. (A) Intact control: normal pellet diet-fed vehicle control mice; administered $10 \mathrm{ml} / \mathrm{kg}$ of distilled water orally. (B) HFD (vehicle) control, $10 \mathrm{ml} / \mathrm{kg}$ of distilled water administered orally with HFD supply. (C) Simvastatin, $10 \mathrm{mg} / \mathrm{kg}$ of simvastatin administered with HFD supply. (D) YPh $500,500 \mathrm{mg} / \mathrm{kg}$ of YPh administered orally with HFD supply. (E) YPh $250,250 \mathrm{mg} / \mathrm{kg}$ of YPh administered orally with HFD supply. (F) YPh 125, 125 mg/kg of YPh administered orally with HFD supply; NFD, normal fat pellet die; HFD, 45\% kcal high-fat diet; YPh, yellow(head) catfish or Korean bullhead (Tachysurus fulvidraco) protein hydrolysates, test material; IS, pancreatic islet. PD, pancreatic secretory duct. All images show hematoxylin and eosin staining. Scale bars, $80 \mu \mathrm{m}$.

all test substance-treated mice compared with the HFD-fed controls (Table VII).

Effects on serum creatinine levels. A significant $(\mathrm{p}<0.01)$ increase in serum creatinine levels was detected in the HFD-fed controls compared with the intact controls. However, the serum creatinine levels decreased significantly $(\mathrm{p}<0.01)$ in all the test substance-treated HFD-fed mice compared with the HFD-fed control mice (Table VII).

Effects on kidney histopathology. A significant $(\mathrm{p}<0.01)$ increase in the number of degenerative vacuolated renal tubules was detected in the HFD-fed controls compared with the intact controls, resulting from lipid droplet-deposited diabetic nephropathy; however, these nephropathies were significantly $(\mathrm{p}<0.01)$ normalized by treatment with all of the test substances, including $10 \mathrm{mg} / \mathrm{kg}$ simvastatin, compared with the HFD-fed controls (Table V and Fig. 8).

\section{Effects on liver lipid peroxidation and the antioxidant defense system}

Effects on liver lipid peroxidation. A significant $(\mathrm{p}<0.01)$ increase in liver lipid peroxidation (MDA content) was detected in the HFD-fed controls compared with the intact controls; 
Table VI. Changes on serum lipid contents in NFD- or HFD-fed mice.

\begin{tabular}{|c|c|c|c|c|}
\hline Groups & $\begin{array}{l}\text { Total cholesterol } \\
(\mathrm{mg} / \mathrm{dl})\end{array}$ & $\begin{array}{l}\text { Triglyceride } \\
\text { (mg/dl) }\end{array}$ & $\begin{array}{l}\text { Low-density lipoprotein } \\
\qquad(\mathrm{mg} / \mathrm{dl})\end{array}$ & $\begin{array}{l}\text { High-density lipoprotein } \\
(\mathrm{mg} / \mathrm{dl})\end{array}$ \\
\hline \multicolumn{5}{|l|}{ Controls } \\
\hline Intact & $113.88 \pm 21.26$ & $50.63 \pm 18.52$ & $16.13 \pm 1.64$ & $105.00 \pm 22.61$ \\
\hline HFD & $279.13 \pm 36.98^{a}$ & $215.13 \pm 23.42^{\mathrm{a}}$ & $49.13 \pm 9.49^{d}$ & $23.50 \pm 10.25^{\mathrm{a}}$ \\
\hline \multicolumn{5}{|l|}{ Reference } \\
\hline Simvastatin & $172.13 \pm 36.21^{\mathrm{a}, \mathrm{c}}$ & $119.25 \pm 34.51^{\mathrm{a}, \mathrm{c}}$ & $22.63 \pm 4.37^{\mathrm{d}, \mathrm{e}}$ & $74.38 \pm 10.64^{\mathrm{a}, \mathrm{c}}$ \\
\hline \multicolumn{5}{|l|}{$\mathrm{YPh}$ treated } \\
\hline $500 \mathrm{mg} / \mathrm{kg}$ & $158.75 \pm 27.75^{\mathrm{b}, \mathrm{c}}$ & $100.88 \pm 24.33^{\mathrm{a}, \mathrm{c}}$ & $20.75 \pm 1.91^{\mathrm{d}, \mathrm{e}}$ & $83.13 \pm 13.73^{\mathrm{a}, \mathrm{c}}$ \\
\hline $250 \mathrm{mg} / \mathrm{kg}$ & $192.13 \pm 37.31^{\mathrm{a}, \mathrm{c}}$ & $131.13 \pm 23.90^{\mathrm{a}, \mathrm{c}}$ & $24.88 \pm 3.68^{\mathrm{d}, \mathrm{e}}$ & $68.50 \pm 16.96^{\mathrm{a}, \mathrm{c}}$ \\
\hline $125 \mathrm{mg} / \mathrm{kg}$ & $213.75 \pm 33.40^{\mathrm{a}, \mathrm{c}}$ & $162.25 \pm 37.09^{\mathrm{a}, \mathrm{c}}$ & $31.75 \pm 7.09^{\mathrm{d}, \mathrm{e}}$ & $49.75 \pm 14.20^{\mathrm{a}, \mathrm{c}}$ \\
\hline
\end{tabular}

Table VII. Changes in serum AST, ALT, BUN and creatine levels in NFD- or HFD-fed mice.

\begin{tabular}{lcccc}
\hline Groups & $\begin{array}{c}\text { AST } \\
\text { (IU/l) }\end{array}$ & $\begin{array}{c}\text { ALT } \\
(\mathrm{IU} / \mathrm{l})\end{array}$ & $\begin{array}{c}\text { BUN } \\
(\mathrm{mg} / \mathrm{dl})\end{array}$ & $\begin{array}{c}\text { Creatinine } \\
(\mathrm{mg} / \mathrm{dl})\end{array}$ \\
\hline Controls & & & & \\
Intact & $74.50 \pm 14.19$ & $33.50 \pm 11.41$ & $34.75 \pm 10.39$ & $0.66 \pm 0.21$ \\
HFD & $226.75 \pm 23.23^{\mathrm{d}}$ & $169.00 \pm 18.67^{\mathrm{a}}$ & $97.38 \pm 16.05^{\mathrm{a}}$ & $2.19 \pm 0.24^{\mathrm{d}}$ \\
Reference & & & \\
Simvastatin & $121.50 \pm 30.34^{\mathrm{d}, \mathrm{f}}$ & $77.00 \pm 18.55^{\mathrm{a}, \mathrm{c}}$ & $61.25 \pm 9.22^{\mathrm{a}, \mathrm{c}}$ & $1.20 \pm 0.08^{\mathrm{d}, \mathrm{f}}$ \\
YPh-treated & & & & \\
$500 \mathrm{mg} / \mathrm{kg}$ & $96.50 \pm 16.20^{\mathrm{e}, \mathrm{f}}$ & $61.38 \pm 21.25^{\mathrm{a}, \mathrm{c}}$ & $50.00 \pm 11.90^{\mathrm{b}, \mathrm{c}}$ & $0.96 \pm 0.25^{\mathrm{e}, \mathrm{f}}$ \\
$250 \mathrm{mg} / \mathrm{kg}$ & $127.50 \pm 18.75^{\mathrm{d}, \mathrm{f}}$ & $87.50 \pm 14.52^{\mathrm{a}, \mathrm{c}}$ & $63.13 \pm 10.41^{\mathrm{a}, \mathrm{c}}$ & $1.34 \pm 0.23^{\mathrm{d}, \mathrm{f}}$ \\
$125 \mathrm{mg} / \mathrm{kg}$ & $167.00 \pm 22.46^{\mathrm{d}, \mathrm{f}}$ & $111.88 \pm 11.93^{\mathrm{a}, \mathrm{c}}$ & $74.13 \pm 10.11^{\mathrm{a}, \mathrm{c}}$ & $1.60 \pm 0.26^{\mathrm{d}, \mathrm{f}}$ \\
\hline
\end{tabular}

Values are expressed as the means \pm SD of 8 mice. NFD, normal fat pellet diet; HFD, 45\% kcal high-fat diet; YPh, yellow(head) catfish or Korean bullhead (Tachysurus fulvidraco) protein hydrolysates, test material. Simvastatin was administrated at dose levels of $10 \mathrm{mg} / \mathrm{kg}$. ALT, alanine aminotransferase; AST, aspartate aminotransferase; BUN, blood urea nitrogen. ${ }^{\mathrm{a}} \mathrm{p}<0.01$ and ${ }^{\mathrm{b}} \mathrm{p}<0.05$ as compared with the intact control as shown by the LSD test; ${ }^{c} p<0.01$ as compared with the HFD-fed control as shown by the LSD test; ${ }^{\mathrm{d}} \mathrm{p}<0.01$ and ${ }^{\mathrm{e}} \mathrm{p}<0.05$ as compared with the intact control as shown by the Mann-Whitney U test; ${ }^{\mathrm{f}} \mathrm{p}<0.01$ as compared with the HFD-fed control as shown by the Mann-Whitney U test.

however, these effects were significantly $(\mathrm{p}<0.01)$ normalized by treatment with all of the test substances, including $10 \mathrm{mg} / \mathrm{kg}$ simvastatin, compared with HFD-fed control mice (Table VIII).

Effects on hepatic GSH content. A significant $(\mathrm{p}<0.01)$ decrease in the content of hepatic GSH, a representative endogenous antioxidant, was detected in the HFD-fed controls compared with the intact controls. However, the hepatic GSH content $(\mathrm{p}<0.01)$ increased significantly in all test substance-treated HFD-fed mice, including the $10 \mathrm{mg} / \mathrm{kg}$ simvastatin-treated mice, compared with the HFD-fed control mice (Table VIII).

Effects on hepatic CAT activity. A significant $(\mathrm{p}<0.01)$ decrease in the activity of hepatic CAT, a representative endogenous antioxidant enzyme, was detected in the HFD-fed controls compared with the intact controls; however, this decreased activity of CAT was significantly $(\mathrm{p}<0.01)$ normalized by treatment with the test substances compared with the HFD-fed controls (Table VIII).

Effects on hepatic SOD activity. A significant $(\mathrm{p}<0.01)$ decrease in the activity of hepatic SOD, another representative endogenous antioxidant enzyme, was detected in the HFD-fed controls compared with the intact controls; however, this effect was significantly $(\mathrm{p}<0.01)$ normalized by treatment with all of the test substances, including $10 \mathrm{mg} / \mathrm{kg}$ simvastatin, compared with HFD-fed control mice (Table VIII).

\section{Discussion}

In the present study, we observed the true pharmacological activities of $\mathrm{YPh}$ in obese mice with mild diabetes fed a HFD, 
Table VIII. Changes on the liver lipid peroxidation and antioxidant defense systems in NFD- or HFD-fed mice.

\begin{tabular}{|c|c|c|c|c|}
\hline \multirow[b]{2}{*}{ Groups } & \multicolumn{2}{|c|}{ Lipid peroxidation } & \multicolumn{2}{|c|}{ Antioxidant defense system } \\
\hline & $\begin{array}{l}\text { Malondialdehyde } \\
\text { (nM/mg tissue) }\end{array}$ & $\begin{array}{c}\text { Glutathione } \\
(\mu \mathrm{M} / \mathrm{mg} \text { tissue })\end{array}$ & $\begin{array}{c}\text { Catalase } \\
\text { (U/mg tissue) }\end{array}$ & $\begin{array}{c}\text { SOD } \\
(\mathrm{U} / \mathrm{mg} \text { tissue })\end{array}$ \\
\hline \multicolumn{5}{|l|}{ Controls } \\
\hline Intact & $11.57 \pm 1.89$ & $35.91 \pm 6.38$ & $30.81 \pm 7.18$ & $3.31 \pm 1.02$ \\
\hline HFD & $31.14 \pm 7.01^{\mathrm{a}}$ & $10.99 \pm 2.29^{\mathrm{d}}$ & $10.33 \pm 2.51^{\mathrm{d}}$ & $0.87 \pm 0.13^{\mathrm{d}}$ \\
\hline \multicolumn{5}{|l|}{ Reference } \\
\hline Simvastatin & $19.59 \pm 3.90^{\mathrm{a}, \mathrm{c}}$ & $22.31 \pm 3.52^{\mathrm{d}, \mathrm{f}}$ & $18.64 \pm 1.77^{\mathrm{d}, \mathrm{f}}$ & $2.03 \pm 0.35^{\mathrm{d}, \mathrm{f}}$ \\
\hline \multicolumn{5}{|l|}{ YPh-treated } \\
\hline $500 \mathrm{mg} / \mathrm{kg}$ & $16.63 \pm 3.09^{\mathrm{b}, \mathrm{c}}$ & $30.65 \pm 6.50^{\mathrm{f}}$ & $22.56 \pm 3.93^{\mathrm{d}, \mathrm{f}}$ & $2.29 \pm 0.49^{\mathrm{e}, \mathrm{f}}$ \\
\hline $250 \mathrm{mg} / \mathrm{kg}$ & $21.20 \pm 3.16^{\mathrm{a}, \mathrm{c}}$ & $21.86 \pm 2.94^{\mathrm{d}, \mathrm{f}}$ & $17.83 \pm 2.85^{\mathrm{d}, \mathrm{f}}$ & $1.97 \pm 0.13^{\mathrm{d}, \mathrm{f}}$ \\
\hline $125 \mathrm{mg} / \mathrm{kg}$ & $22.64 \pm 3.27^{\mathrm{a}, \mathrm{c}}$ & $16.26 \pm 3.03^{\mathrm{d}, \mathrm{f}}$ & $16.16 \pm 1.53^{\mathrm{d}, \mathrm{f}}$ & $1.62 \pm 0.39^{\mathrm{d}, \mathrm{f}}$ \\
\hline
\end{tabular}

Values are expressed as the means \pm SD of 8 mice. NFD, normal fat pellet diet; HFD, $45 \%$ kcal high fat diet; YPh, yellow(head) catfish or Korean bullhead (Tachysurus fulvidraco) protein hydrolysates, test material; SOD, superoxide dismutase. Simvastatin was administrated at dose levels of $10 \mathrm{mg} / \mathrm{kg} .{ }^{\mathrm{a}} \mathrm{p}<0.01$ and ${ }^{\mathrm{b}} \mathrm{p}<0.05$ as compared with the intact controls as shown by the LSD test; ${ }^{\mathrm{c}} \mathrm{p}<0.01$ as compared with the HFD-fed controls as shown by the LSD test; ${ }^{\mathrm{d}} \mathrm{p}<0.01$ and ${ }^{\mathrm{e}} \mathrm{p}<0.05$ as compared with the intact controls as shown by the Mann-Whitney U test; ${ }^{\mathrm{f}} \mathrm{p}<0.01$ as compared with the HFD-fed controls as shown by the Mann-Whitney U test.

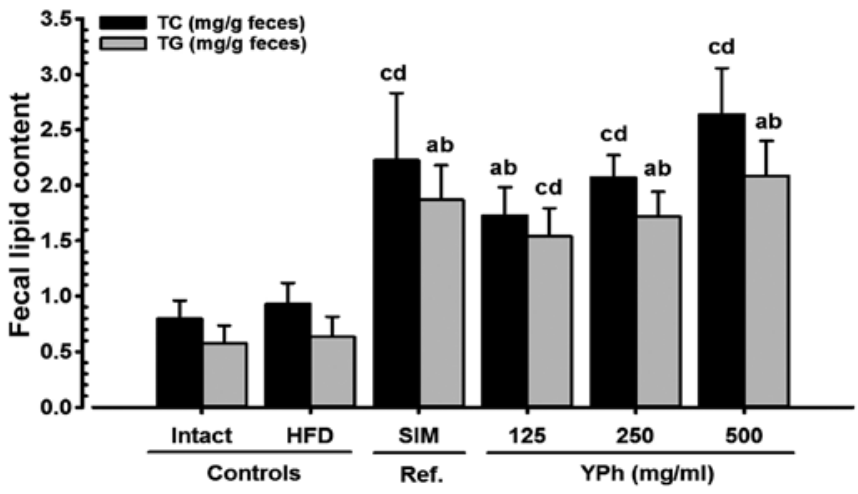

Figure 6. Fecal TC and TG Content in NFD- or HFD-fed mice. Although a slight but non-significant increase in fecal TC and TG contents was detected in the HFD-fed controls as compared with the intact controls, the fecal TC and TG contents in the mice treated with all test materials, including YPh $500 \mathrm{mg}$ / $\mathrm{kg}$ were significantly $(\mathrm{p}<0.01)$ elevated as compared with the HFD-fed control mice. Values are expressed as the means \pm SD of 8 mice. NFD, normal fat pellet die; HFD, 45\% kcal high-fat diet; SIM, simvastatin; MET, metformin; YPh, yellow(head) catfish or Korean bullhead (Tachysurus fulvidraco) protein hydrolysates, test material; DXA, dual-energy X-ray absorptionmetry. Simvastatin (SIM) was administrated at dose levels of $10 \mathrm{mg} / \mathrm{kg} .{ }^{\mathrm{a}} \mathrm{p}<0.01$ as compared with intact control by LSD test; ${ }^{\mathrm{b}} \mathrm{p}<0.01$ as compared with the HFD-fed controls as shown by the LSD test; ${ }^{c} \mathrm{p}<0.01$ as compared with the intact controls as shown by the Mann-Whitney $U$ test; ${ }^{\mathrm{d}} \mathrm{p}<0.01$ as compared with the HFD-fed controls as shown by the Mann-Whitney U test.

as previously described (12,33-35). Simvastatin $(10 \mathrm{mg} / \mathrm{kg})$ is a lipid-lowering medication $(14,15)$ used in the treatment of dyslipidemia and for the prevention of cardiovascular disease in patients with diabetes $(12,13,18,19)$. The YPh doses in the present study were selected based on in vivo efficacy tests of individual herbal extracts by other investigators. The readily adapted mice to the HFD were selected after a 7-day adaption period and were divided into 6 groups. At the end of 12 weeks of continuous orally administered YPh $(500,250$ and $125 \mathrm{mg} / \mathrm{kg})$ or $10 \mathrm{mg} / \mathrm{kg}$ simvastatin, the hepatoprotective, hypolipidemic, nephroprotective and anti-obesity effects were analyzed separately.

Obesity in mice develops by feeding on a HFD, having the characteristics of hypolipidemia and hepatic steatosis $(12,13,33,34,50,51)$. On the other hand, animals fed a HFD develop hyperglycemia and mild obesity and can be used to identify agents that could be used to prevent metabolic syndrome (52). In this study, we only selected mice that were adapted to the HFD and exhibited a regular increase in body weight compared with the intact controls (normal diet) during the first 7 days of feeding (Table I). The HFD-fed control mice exhibited a significant increase in body weight compared with the intact mice, beginning the first 7 days after the HFD feeding began, and body weight gains during the 7 days of adapting to HFD and the 84 days of administration also increased significantly compared with those of the intact controls (Table II and Fig. 1). However, the increase in body mass and weight was significantly and dose-dependently inhibited by treatment with simvastatin and YPh (Table II and Fig. 1). Obesity is mainly characterized by an increase in fat deposition in the body and the expansion in the intra-abdominal adipose tissues in rodents is caused by cellular hypertrophy $(12,13,39,53,54)$. Adipose tissue is not simply an energy storage organ, but also an endocrine and secretory organ (55). Adipokines are secreted by the adipose tissues, and changes in the action, secretion and expression of adipokines are involved in the development of various syndromes, including insulin resistance $(39,55,56)$. In the present study, treatment with YPh significantly and dose-dependently inhibited the accumulation of fat and adipocyte hypertrophy (Table III), providing direct evidence that YPh has clear anti-obesity effects in HFD-fed mice. In this study, the $10 \mathrm{mg} / \mathrm{kg}$ simvastatin-treated mice also exhibited a noticeable decrease in fat accumulation and mean white adipocyte diameter according to the DXA and histopathological analyses (Table VI and Figs. 2 and 4). 


\section{H\&E stain}

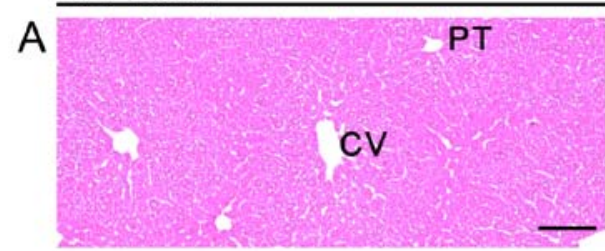

B
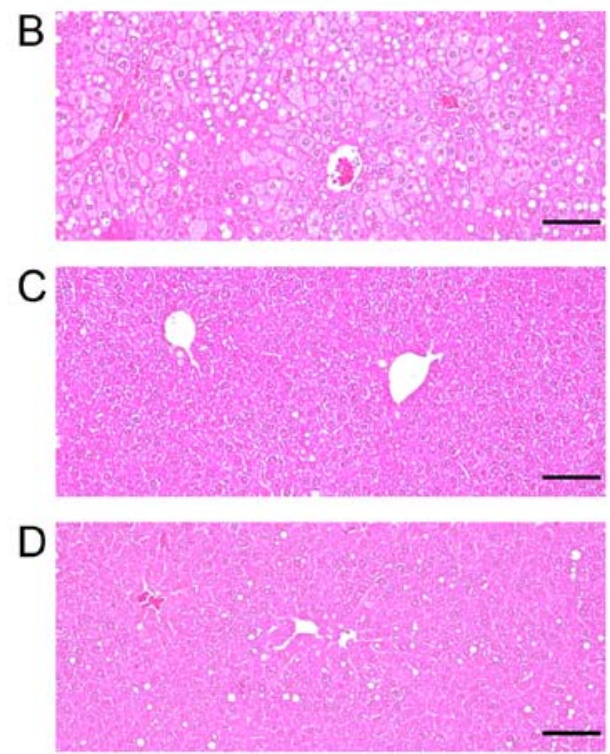

$\mathrm{E}$
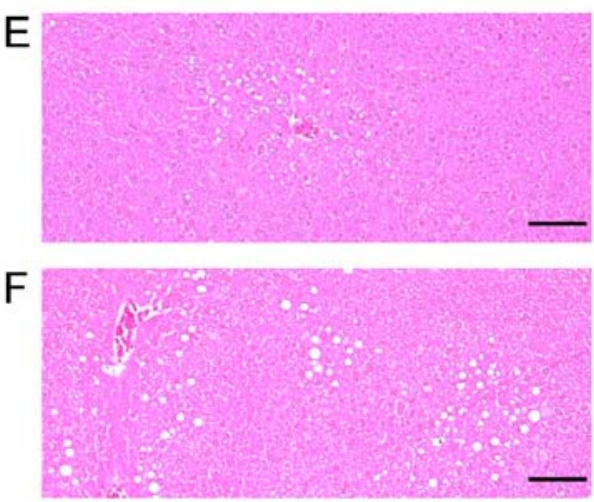

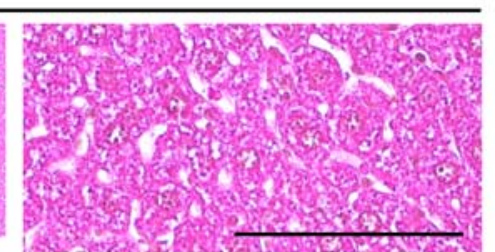

Oil Red Ostain
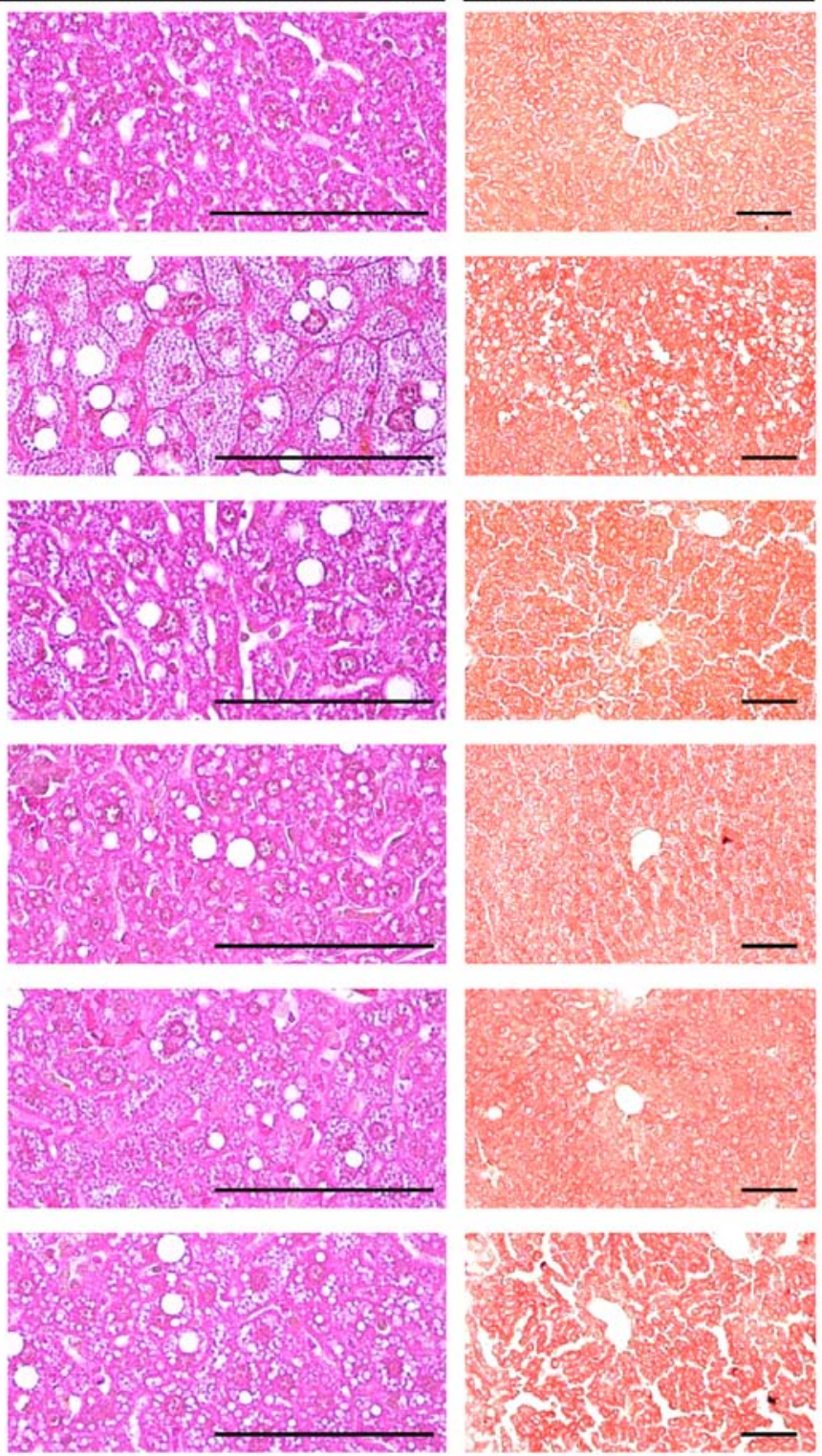

Figure 7. Representative histological images of the liver, taken from NFD- or HFD-fed mice. Note that a marked increase in steatohepatitis, the percentage of fatty-altered regions in the liver parenchyma, was detected in the HFD-fed controls as compared with the intact controls, resulting from severe hypertrophy of hepatocyte-related to intracellular lipid depositions. However, steatohepatitis was normalized by treatment with all test substances, including YPh $250 \mathrm{mg} / \mathrm{kg}$. In particular, the YPh 500, 250 and $125 \mathrm{mg} / \mathrm{kg}$-treated HFD-fed mice also exhibited a noticeable decrease in the steatohepatitis-affected regions and related hepatocyte hypertrophy as compared with the HFD-fed mice. (A) Intact control: normal pellet diet-fed vehicle control mice; administered 10 ml/kg of distilled water orally. (B) HFD (vehicle) control, $10 \mathrm{ml} / \mathrm{kg}$ of distilled water administered orally with HFD supply. (C) Simvastatin, $10 \mathrm{mg} / \mathrm{kg}$ of simvastatin administered with HFD supply. (D) YPh 500, $500 \mathrm{mg} / \mathrm{kg}$ of YPh administered orally with HFD supply. (E) YPh 250, $250 \mathrm{mg} / \mathrm{kg}$ of YPh administered orally with HFD supply. (F) YPh 125, $125 \mathrm{mg} / \mathrm{kg}$ of YPh administered orally with HFD supply; NFD, normal fat pellet die; HFD, 45\% kcal high-fat diet; YPh, yellow(head) catfish or Korean bullhead (Tachysurus fulvidraco) protein hydrolysates, test material; CV, central vein; PT, portal triad. Scale bars, $80 \mu \mathrm{m}$.

The decrease in mean daily food consumption in all HFD-fed mice compared with those fed the normal diet was not unexpected in our study as the energy content of the HFD $(4.73 \mathrm{kcal} / \mathrm{g})$ was much higher (approximately 20-fold) (Table I) than that of the normal diet $(0.21 \mathrm{kcal} / \mathrm{g})$. A similar decrease in daily food consumption in the HFD- fed mice has been reported $(13,39)$. In the present study, no changes in mean daily food consumption were detected among all the test substance-administered groups compared with the HFD-fed control (Table II), suggesting that it was difficult to use the pharmacological effects of the test substances to consider the effects of lower food consumption.
Obese subjects often develop acinar cell atrophy, pancreatic steatosis and the number of zymogen granules decreases $(39,57,58)$. An increase in the number of zymogen granules in exocrine pancreatic acinar cells directs the production of lipid and protein digestive enzymes (59). In the present study, a decrease in the number of pancreatic zymogen granules was also noted in the HFD-fed control mice as compared with the intact controls. However, the decrease in zymogen deposits in the exocrine pancreas was dose-dependently inhibited by YPh treatment, but not by treatment with $10 \mathrm{mg} / \mathrm{kg}$ simvastatin (Table V and Fig. 5). The findings revealed that YPh exerted 

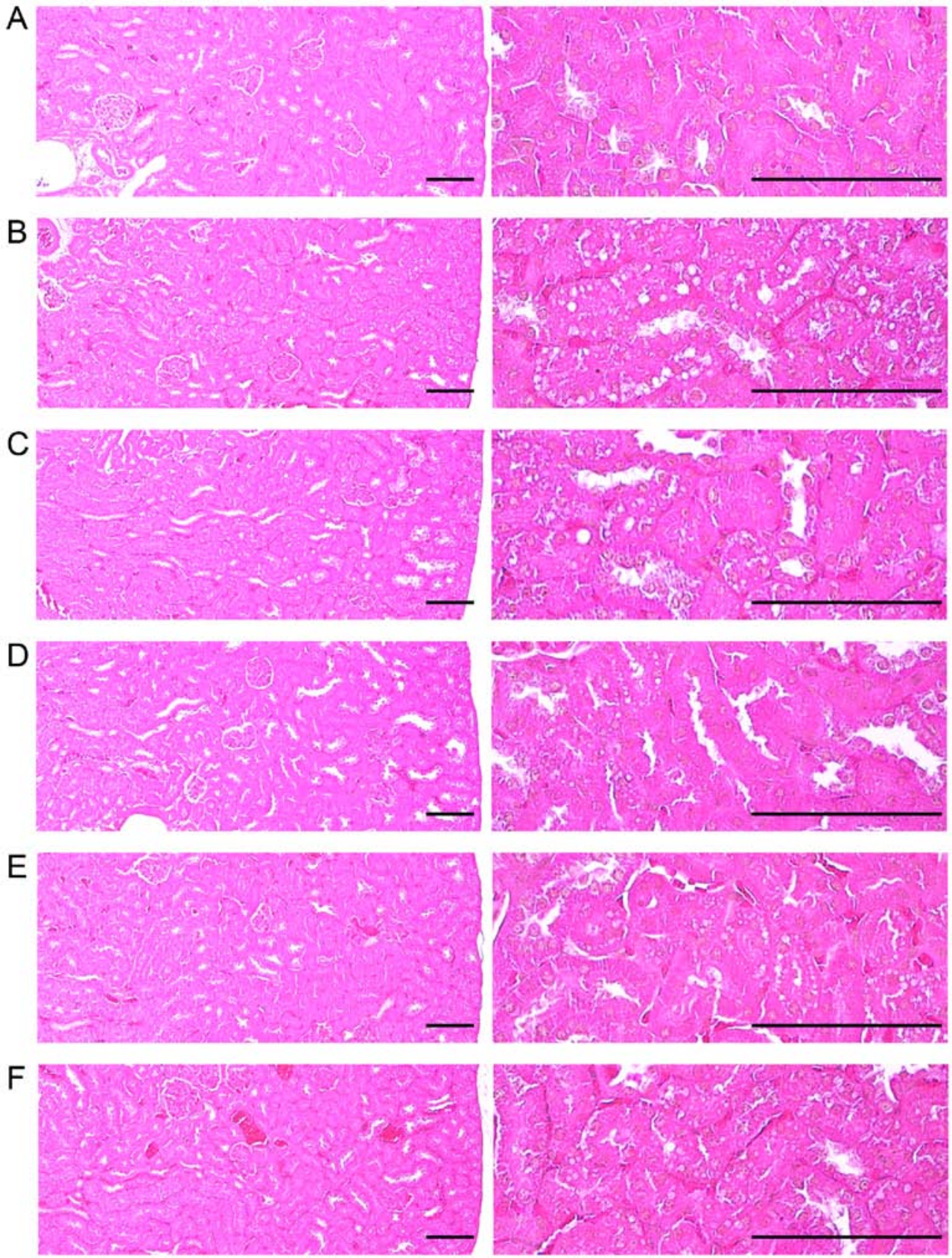

Figure 8. Representative histological images of the kidneys, taken from NFD- or HFD-fed mice. Note that a significant increase in degenerative vacuolated renal tubules was detected in the HFD-fed controls as compared with the intact controls, resulting from lipid droplet deposited nephropathies; however, these effects were significantly normalized by treatment with all test substances, including simvastatin $10 \mathrm{mg} / \mathrm{kg}$ as compared with the HFD-fed controls. (A) Intact control: normal pellet diet-fed vehicle control mice; administered $10 \mathrm{ml} / \mathrm{kg}$ of distilled water orally. (B) HFD (vehicle) control, $10 \mathrm{ml} / \mathrm{kg}$ of distilled water administered orally with HFD supply. (C) Simvastatin, $10 \mathrm{mg} / \mathrm{kg}$ of simvastatin administered with HFD supply. (D) $\mathrm{YPh} 500,500 \mathrm{mg} / \mathrm{kg}$ of YPh administered orally with HFD supply. (E) YPh 250, $250 \mathrm{mg} / \mathrm{kg}$ of YPh administered orally with HFD supply. (F) YPh 125, $125 \mathrm{mg} / \mathrm{kg}$ of YPh administered orally with HFD supply; NFD, normal fat pellet die; HFD, 45\% kcal high-fat diet; YPh, yellow(head) catfish or Korean bullhead (Tachysurus fulvidraco) protein hydrolysates, test material. All images shown hematoxylin and eosin staining. Scale bars, $80 \mu \mathrm{m}$.

anti-obesity effects in HFD-fed mice that may be intervened by inhibiting lipid digestion and decreasing pancreatic enzyme production or release. Simvastatin $(10 \mathrm{mg} / \mathrm{kg})$ did not affect the zymogen granule-occupied regions in the exocrine pancreas compared with HFD-fed control mice (Table V and Fig. 5).

We could not completely exclude the possibility that $\mathrm{YPh}$ increased digestive tract motility; thus, more detailed mechanistic studies are warranted in the future. The rise in digestive tract motility also increases excretion, resulting in a decrease in body weight (60-62). In this study, we observed a substantial increase in the fecal TG and TC contents in response to all $\mathrm{YPh}$ treatments and $10 \mathrm{mg} / \mathrm{kg}$ simvastatin (Fig. 6). The slight increase in fecal TG and TC contents noted in the HFD-fed control mice in this study was considered to be the secondary effects of consuming the HFD.

Hyperlipidemia generally occurs during the chronic progression of diabetes in HFD-fed mice (63). As the most critical issue in hyperlipidemia is increased serum TC, TG and LDL levels and decreased HDL levels $(12,13,64)$, the efficacy of hypolipidemic agents is generally evaluated based on the 
decrease in serum TC, TG and LDL levels as HDL levels increase $(12,13,39,65)$. In the present study, all 3 doses of $\mathrm{YPh}$ $(500,250$ and $125 \mathrm{mg} / \mathrm{kg}$ ) effectively and dose-dependently decreased serum TC, TG and LDL levels, but favorably increased serum HDL levels compared with those in the HFD-fed control mice, suggesting that YPh has favorable hypolipidemic effects in HFD-fed mice, which may be mediated by inhibiting lipid digestion due to the decrease in pancreatic enzyme production or release in this experiment (Table VI). In particular, $250 \mathrm{mg} /$ $\mathrm{kg} \mathrm{YPh}$ exerted comparable hypolipidemic effects to those of $10 \mathrm{mg} / \mathrm{kg}$ simvastatin in HFD-fed mice (Table VI). These hypolipidemic properties of the test substances were also due to decreased lipid absorption and elimination of lipids in feces.

As obesity progresses, liver weight increases due to abnormal glycosylation and fibrosis related to hepatocyte hypertrophy and hepatosteatosis, due to lipid deposition in the cytoplasm along with increased serum ALT and AST levels $(13,39,66)$. The attenuation of these abnormalities depicts attenuated hepatopathy (66). AST is detectable in numerous body tissues, but is principally high in striated muscle and the liver. Elevated serum AST activity and no increase in ALT levels indicate muscle necrosis, but AST activity increases more slowly than that of ALT with liver damage. This indicates complete cellular disruption as ALT leaks only from necrotic cells (67). ALT is present in large quantities in the cytoplasm of hepatocytes and it enters the blood when liver cells are destroyed or damaged. This enzyme is a sensitive indicator of active liver damage, but does not indicate the cause or reversibility of the damage (67). In the present study, all 3 different YPh doses effectively attenuated hepatopathy compared with the HFD-fed control mice, suggesting that $\mathrm{YPh}$ has favorable hepatoprotective effects in HFD-fed mice. Simvastatin also exerted favorable inhibitory effects on the increased liver weight (Table III), serum ALT and AST (Table VII), and related hepatocyte hypertrophic and histopathological steatohepatitis induced by feeding the HFD (Table V and Fig. 6).

As obesity progresses, kidney weight also increases due to swelling, inflammation and necrosis along with the elevation of serum creatinine and BUN levels, or so-called nephropathy. The attenuation in these abnormalities is direct evidence of attenuated nephropathy $(13,39)$. BUN is the amount of urea nitrogen (protein metabolic product) in the blood. High BUN levels generally cause renal disease. Creatinine is a non-protein nitrogenous product of muscle metabolism, and serum creatinine levels increase with conditions that reduce glomerular filtration (67). In this study, HFD-fed mice exhibited a marked increase in absolute kidney weight and increased creatinine and serum BUN levels with lipid droplet deposition related to vacuolation of the renal tubules, suggesting a mild nephropathy, but they were normalized by all $3 \mathrm{YPh}$ doses and simvastatin, indicating that they have favorable nephroprotective effects (Tables III and VII and Fig. 8).

Considerable evidence indicates a role for free radicals in the altered antioxidant defense in the etiology of diabetes (68). Diabetes mellitus from its genesis to the development of microvascular complications is affected by oxidative stress. Free radicals are generated by hyperglycemia due to glucose autooxidation. Glycosylated proteins are a source of reactive oxygen species (ROS) $(39,69)$. Oxidative stress is linked to a decrease in the antioxidant status (70) which could alter the deleterious effects of free radicals. ROS-related oxidative stress plays an important role in the etiology of complications from obesity (71). Various toxic substances generated from lipid peroxidation have been demonstrated in HFD-fed mice, where they act as a potent redox cycler by generating harmful ROS and damage organs $(73,74)$. GSH is a representative endogenous antioxidant that inhibits tissue damage by maintaining ROS at low levels and is a protective antioxidant in tissues (75).

CAT catalyzes the conversion of $\mathrm{H}_{2} \mathrm{O}_{2}$ to $\mathrm{H}_{2} \mathrm{O}$ and SOD is an antioxidant enzyme that contributes to enzymatic defense mechanisms (76). Decreased endogenous antioxidants, GSH content and increased lipid peroxidation, antioxidant enzymes, CAT and SOD activities occur in damaged liver tissues, and as a secondary role help to combat obesity and various related complications (77,78). In this study, a marked depleted GSH content, elevation of hepatic lipid peroxidation, and decreased CAT and SOD activities were noted in the HFD-fed control mice, which was similar to other reported HFD-fed mice studies $(79,80)$. In the present study, all $3 \mathrm{YPh}$ concentrations dose-dependently inhibited the deterioration in the hepatic antioxidant defense system compared with the HFD=-fed control mice, suggesting favorable antioxidant effects of YPh on HFD mice. Simvastatin also exerted favorable antioxidant effects (Table VIII).

In conclusion, the results of this study suggest that $\mathrm{YPh}$ exerts potent anti-obesity and complication-ameliorating effects in HFD-fed mice by enhancing the modulating effects of hepatic glucose enzyme and antioxidant activities, as well as pancreatic lipid digestive enzymes. The overall effects of $250 \mathrm{mg} / \mathrm{kg}$ YPh on HFD-induced diabetes and related complications were similar or more potent than those of $10 \mathrm{mg} / \mathrm{kg}$ simvastatin in this study. Accordingly, $\mathrm{YPh}$ is a promising novel medicinal ingredient which may has potential for use in the treatment of obesity and related complications.

\section{Acknowledgements}

This study was a component of the project (no. 20130285) entitled 'Development of high value material and bioactive components from freshwater fish', funded by the Ministry of Oceans and Fisheries, Korea.

\section{References}

1. Wendel AA, Purushotham A, Liu LF and Belury MA: Conjugated linoleic acid fails to worsen insulin resistance but induces hepatic steatosis in the presence of leptin in ob/ob mice. J Lipid Res 49: 98-106, 2008

2. Tilg H and Moschen AR: Adipocytokines: Mediators linking adipose tissue, inflammation and immunity. Nat Rev Immunol 6: 772-783, 2006.

3. James PT, Leach R, Kalamara E and Shayeghi M: The worldwide obesity epidemic. Obes Res 9 (Suppl 4): 228S-233S, 2001.

4. Zimmet P: The burden of type 2 diabetes: are we doing enough? Diabetes Metab 29: 6S9-6S18, 2003.

5. Kunitomi M, Wada J, Takahashi K, Tsuchiyama Y, Mimura Y, Hida K, Miyatake N, Fujii M, Kira S, Shikata K, et al: Relationship between reduced serum IGF-I levels and accumulation of visceral fat in Japanese men. Int J Obes Relat Metab Disord 26: 361-369, 2002.

6. Hida K, Wada J, Eguchi J, Zhang H, Baba M, Seida A, Hashimoto I, Okada T, Yasuhara A, Nakatsuka A, et al: Visceral adipose tissue-derived serine protease inhibitor: A unique insulin-sensitizing adipocytokine in obesity. Proc Natl Acad Sci USA 102: 10610-10615, 2005.

7. Lebovitz HE: Insulin resistance: Definition and consequences. Exp Clin Endocrinol Diabetes 109 (Suppl 2): S135-S148, 2001. 
8. Goldstein BJ: Insulin resistance as the core defect in type 2 diabetes mellitus. Am J Cardiol 90: 3G-10G, 2002.

9. Angulo P: Nonalcoholic fatty liver disease. N Engl J Med 346: $1221-1231,2002$

10. Kadowaki T and Yamauchi T: Adiponectin and adiponectin receptors. Endocr Rev 26: 439-451, 2005.

11. Inzucchi SE: Oral antihyperglycemic therapy for type 2 diabetes: Scientific review. JAMA 287: 360-372, 2002.

12. Jung YM, Lee SH, Lee DS, You MJ, Chung IK, Cheon WH, Kwon YS, Lee YJ and Ku SK: Fermented garlic protects diabetic, obese mice when fed a high-fat diet by antioxidant effects. Nutr Res 31: 387-396, 2011.

13. Kim CM, Yi SJ, Cho IJ and Ku SK: Red-koji fermented red ginseng ameliorates high fat diet-induced metabolic disorders in mice. Nutrients 5: 4316-4332, 2013.

14. Föger B: Lipid lowering therapy in type 2 diabetes. Wien Med Wochenschr 161: 289-296, 2011.

15. Desai CS, Martin SS and Blumenthal RS: Non-cardiovascular effects associated with statins. BMJ 349: g3743, 2014.

16. Wei P, Grimm PR, Settles DC, Balwanz CR, Padanilam BJ and Sansom SC: Simvastatin reverses podocyte injury but not mesangial expansion in early stage type 2 diabetes mellitus. Ren Fail 31: 503-513, 2009.

17. Wang L, Duan G, Lu Y, Pang S, Huang X, Jiang Q and Dang N: The effect of simvastatin on glucose homeostasis in streptozotocin induced type 2 diabetic rats. J Diabetes Res 2013 274986, 2013.

18. American Diabetes Association: Management of dyslipidemia in adults with diabetes. Diabetes Care 25: S74-S77, 2002.

19. Wald NJ and Law MR: A strategy to reduce cardiovascular disease by more than 80\%. BMJ 326: 1419, 2003.

20. Abbas AM and Sakr HF: Simvastatin and vitamin E effects on cardiac and hepatic oxidative stress in rats fed on high fat diet. J Physiol Biochem 69: 737-750, 2013.

21. Cui B, Liu S, Lin X, Wang J, Li S, Wang Q and Li S: Effects of Lycium barbarum aqueous and ethanol extracts on high-fatdiet induced oxidative stress in rat liver tissue. Molecules 16 9116-9128, 2011

22. Simsek Ozek N, Bal IB, Sara Y, Onur R and Severcan F: Structural and functional characterization of simvastatin-induced myotoxicity in different skeletal muscles. Biochim Biophys Acta 1840: 406-415, 2014.

23. Magni P, Macchi C, Morlotti B, Sirtori CR and Ruscica M: Risk identification and possible countermeasures for muscle adverse effects during statin therapy. Eur J Intern Med 26: 82-88, 2015.

24. López-Barrios L, Gutiérrez-Uribe JA and Serna-Saldívar SO: Bioactive peptides and hydrolysates from pulses and their potential use as functional ingredients. J Food Sci 79: R273-R283, 2014.

25. Nesse KO, Nagalakshmi AP, Marimuthu P and Singh M: Efficacy of a fish protein hydrolysate in malnourished children. Indian $J$ Clin Biochem 26: 360-365, 2011.

26. Ryan JT, Ross RP, Bolton D, Fitzgerald GF and Stanton C: Bioactive peptides from muscle sources: Meat and fish Nutrients 3: 765-791, 2011.

27. Kim KM, Chang UJ, Kang DH, Kim JM, Choi YM and Suh HJ: Yeast hydrolysate reduces body fat of dietary obese rats. Phytother Res 18: 950-953, 2004.

28. Wergedahl H, Gudbrandsen OA, Røst TH and Berge RK: Combination of fish oil and fish protein hydrolysate reduces the plasma cholesterol level with a concurrent increase in hepatic cholesterol level in high-fat-fed Wistar rats. Nutrition 25: 98-104, 2009.

29. Liu X, Zhang M, Zhang C and Liu C: Angiotensin converting enzyme (ACE) inhibitory, antihypertensive and antihyperlipidaemic activities of protein hydrolysates from Rhopilema esculentum. Food Chem 134: 2134-2140, 2012.

30. Mun JM, Ok HM and Kwon O: Corn gluten hydrolysate and capsaicin have complimentary actions on body weight reduction and lipid-related genes in diet-induced obese rats. Nutr Res 34 458-465, 2014

31. Gu Z, Wang J, Li M, Zhang J, Ke X and Gong X: Morphological and genetic differences of Trypanosoma in some Chinese freshwater fishes: Difficulties of species identification. Parasitol Res 101: 723-730, 2007.

32. Chen QL, Luo Z, Zheng JL, Li XD, Liu CX, Zhao YH and Gong Y: Protective effects of calcium on copper toxicity in Pelteobagrus fulvidraco: Copper accumulation, enzymatic activities, histology. Ecotoxicol Environ Saf 76: 126-134, 2012.
33. Yun SN, Moon SJ, Ko SK, Im BO and Chung SH: Wild ginseng prevents the onset of high-fat diet induced hyperglycemia and obesity in ICR mice. Arch Pharm Res 27: 790-796, 2004.

34. Lee JW, Lee KW, Lee SW, Kim IH and Rhee C: Selective increase in pinolenic acid (all-cis-5,9,12-18:3) in Korean pine nut oil by crystallization and its effect on LDL-receptor activity. Lipids 39: 383-387, 2004

35. Kim UH, Yoon JH, Li H, Kang JH, Ji HS, Park KH, Shin DH, Park HY and Jeong TS: Pterocarpan-enriched soy leaf extract ameliorates insulin sensitivity and pancreatic $\beta$-cell proliferation in type 2 diabetic mice. Molecules 19: 18493-18510, 2014.

36. Folch J, Lees M and Sloane Stanley GH: A simple method for the isolation and purification of total lipides from animal tissues. J Biol Chem 226: 497-509, 1957.

37. Allain CC, Poon LS, Chan CSG, Richmond W and Fu PC: Enzymatic determination of total serum cholesterol. Clin Chem 20: 470-475, 1974.

38. McGowan MW, Artiss JD, Strandbergh DR and Zak B: A peroxidase-coupled method for the colorimetric determination of serum triglycerides. Clin Chem 29: 538-542, 1983.

39. Kang SJ, Lee JE, Lee EK, Jung DH, Song CH, Park SJ, Choi SH, $\mathrm{Han} \mathrm{CH}, \mathrm{Ku}$ SK and Lee YJ: Fermentation with Aquilariae Lignum enhances the anti-diabetic activity of green tea in type II diabetic db/db mouse. Nutrients 6: 3536-3571, 2014.

40. Kavutcu M, Canbolat O, Oztürk S, Olcay E, Ulutepe S, Ekinci C, Gökhun IH and Durak I: Reduced enzymatic antioxidant defense mechanism in kidney tissues from gentamicin-treated guinea pigs: Effects of vitamins E and C. Nephron 72: 269-274, 1996.

41. Jamall IS and Smith JC: Effects of cadmium on glutathione peroxidase, superoxide dismutase, and lipid peroxidation in the rat heart: A possible mechanism of cadmium cardiotoxicity. Toxicol Appl Pharmacol 80: 33-42, 1985.

42. Lowry OH, Rosebrough NJ, Farr AL and Randall RJ: Protein measurement with the Folin phenol reagent. J Biol Chem 193: 265-275, 1951.

43. Sedlak J and Lindsay RH: Estimation of total, protein-bound, and nonprotein sulfhydryl groups in tissue with Ellman's reagent. Anal Biochem 25: 192-205, 1968.

44. Aebi H: Catalase. In: Methods in Enzymatic Analysis Bergmeyer HU (ed). Academic Press, New York, pp673-686, 1974.

45. Sun Y, Oberley LW and Li Y: A simple method for clinical assay of superoxide dismutase. Clin Chem 34: 497-500, 1988.

46. Kawakami S, Han KH, Nakamura Y, Shimada K, Kitano T, Aritsuka T, Nagura T, Ohba K, Nakamura K and Fukushima M: Effects of dietary supplementation with betaine on a nonalcoholic steatohepatitis (NASH) mouse model. J Nutr Sci Vitaminol (Tokyo) 58: 371-375, 2012.

47. Lee HS, Chang JH and Ku SK: An immunohistochemical study of the pancreatic endocrine cells of the ddN mouse. Folia Histochem Cytobiol 48: 387-393, 2010.

48. Levene A: Pathological factors influencing excision of tumours in the head and neck. Part I. Clin Otolaryngol Allied Sci 6: 145-151, 1981.

49. Ludbrook J: Update: Microcomputer statistics packages. A personal view. Clin Exp Pharmacol Physiol 24: 294-296, 1997.

50. Surwit RS, Kuhn CM, Cochrane C, McCubbin JA and Feinglos MN: Diet-induced type II diabetes in C57BL/6J mice. Diabetes 37: 1163-1167, 1988

51. Thupari JN, Kim EK, Moran TH, Ronnett GV and Kuhajda FP: Chronic C75 treatment of diet-induced obese mice increases fat oxidation and reduces food intake to reduce adipose mass. Am J Physiol Endocrinol Metab 287: E97-E104, 2004.

52. Park SH, Ko SK and Chung SH: Euonymus alatus prevents the hyperglycemia and hyperlipidemia induced by high-fat diet in ICR mice. J Ethnopharmacol 102: 326-335, 2005.

53. DiGirolamo M, Fine JB, Tagra K and Rossmanith R: Qualitative regional differences in adipose tissue growth and cellularity in male Wistar rats fed ad libitum. Am J Physiol 274: R1460-R1467, 1998.

54. Morange PE, Lijnen HR, Alessi MC, Kopp F, Collen D and Juhan-Vague I: Influence of PAI-1 on adipose tissue growth and metabolic parameters in a murine model of diet-induced obesity. Arterioscler Thromb Vasc Biol 20: 1150-1154, 2000

55. Fujita H, Fujishima H, Koshimura J, Hosoba M, Yoshioka N, Shimotomai T, Morii T, Narita T, Kakei M and Ito S: Effects of antidiabetic treatment with metformin and insulin on serum and adipose tissue adiponectin levels in $\mathrm{db} / \mathrm{db}$ mice. Endocr J 52: 427-433, 2005.

56. Mitchell M, Armstrong DT, Robker RL and Norman RJ: Adipokines: Implications for female fertility and obesity. Reproduction 130: 583-597, 2005. 
57. Tasso F, Clop J and Sarles H: The interaction of ethanol, dietary lipids and proteins on the rat pancreas. II. Ultrastructural study. Digestion 4: 23-34, 1971.

58. Wilson JS, Korsten MA, Leo MA and Lieber CS: Combined effects of protein deficiency and chronic ethanol consumption on rat pancreas. Dig Dis Sci 33: 1250-1259, 1988.

59. Gartner LP and Hiatt JL: Color Textbook of Histology. 3rd edition. Saunders, Philadelphia, pp417-422, 2007.

60. Hyland NP, Rybicka JM, Ho W, Pittman QJ, Macnaughton WK and Sharkey KA: Adaptation of intestinal secretomotor function and nutrient absorption in response to diet-induced obesity. Neurogastroenterol Motil 22: 602-e171, 2010.

61. Bertrand RL, Senadheera S, Markus I, Liu L, Howitt L, Chen H, Murphy TV, Sandow SL and Bertrand PP: A Western diet increases serotonin availability in rat small intestine. Endocrinology 152: 36-47, 2011.

62. Snedeker SM and Hay AG: Do interactions between gut ecology and environmental chemicals contribute to obesity and diabetes? Environ Health Perspect 120: 332-339, 2012.

63. Chen X, Osborne MC, Rybczynski PJ, Zeck R, Yang M, Xu J, Zhou L, Cryan E, Tang Y and Demarest KT: Pharmacological profile of a novel, non-TZD PPARgamma agonist. Diabetes Obes Metab 7: 536-546, 2005.

64. Kamada T, Hata J, Kusunoki H, Ito M, Tanaka S, Kawamura Y, Chayama K and Haruma K: Eradication of Helicobacter pylori increases the incidence of hyperlipidaemia and obesity in peptic ulcer patients. Dig Liver Dis 37: 39-43, 2005.

65. Zdrenghea D, Gligor E, Ossian V and Pop D: The effect of simvastatin associated with ranitidine and alcohol upon serum lipids. Rom J Intern Med 42: 143-148, 2004.

66. Quine SD and Raghu PS: Effects of (-)-epicatechin, a flavonoid on lipid peroxidation and antioxidants in streptozotocin-induced diabetic liver, kidney and heart. Pharmacol Rep 57: 610-615, 2005.

67. Sodikoff $\mathrm{CH}$ : Laboratory profiles of small animal diseases. A guide to laboratory diagnosis. 2nd edition. Mosby Inc., St. Louise, pp1-36, 1995.

68. Garg MC, Singh KP and Bansal DD: Effect of vitamin C supplementation on oxidative stress in experimental diabetes. Indian J Exp Biol 35: 264-266, 1997.

69. Ceriello A, Quatraro A and Giugliano D: New insights on nonenzymatic glycosylation may lead to therapeutic approaches for the prevention of diabetic complications. Diabet Med 9: 297-299, 1992.
70. Collier A, Wilson R, Bradley H, Thomson JA and Small M: Free radical activity in type 2 diabetes. Diabet Med 7: 27-30, 1990.

71. Giugliano D, Ceriello A and Paolisso G: Oxidative stress and diabetic vascular complications. Diabetes Care 19: 257-267, 1996.

72. Comporti M: Lipid peroxidation and cellular damage in toxic liver injury. Lab Invest 53: 599-623, 1985.

73. Lee YM, Gweon OC, Seo YJ, Im J, Kang MJ, Kim MJ and Kim JI: Antioxidant effect of garlic and aged black garlic in animal model of type 2 diabetes mellitus. Nutr Res Pract 3: 156-161, 2009.

74. Jung UJ, Park YB, Kim SR and Choi MS: Supplementation of persimmon leaf ameliorates hyperglycemia, dyslipidemia and hepatic fat accumulation in type 2 diabetic mice. PLoS One 7: e49030, 2012

75. Odabasoglu F, Cakir A, Suleyman H, Aslan A, Bayir Y, Halici $M$ and Kazaz C: Gastroprotective and antioxidant effects of usnic acid on indomethacin-induced gastric ulcer in rats. J Ethnopharmacol 103: 59-65, 2006.

76. Cheeseman KH and Slater TF: An introduction to free radical biochemistry. Br Med Bull 49: 481-493, 1993.

77. Erejuwa OO, Sulaiman SA, Wahab MS, Salam SK, Salleh MS and Gurtu S: Comparison of antioxidant effects of honey, glibenclamide, metformin, and their combinations in the kidneys of streptozotocin-induced diabetic rats. Int J Mol Sci 12: 829-843, 2011.

78. Wu D, Wen W, Qi CL, Zhao RX, Lü JH, Zhong CY and Chen YY: Ameliorative effect of berberine on renal damage in rats with diabetes induced by high-fat diet and streptozotocin. Phytomedicine 19: 712-718, 2012.

79. Chung SI, Rico CW and Kang MY: Comparative study on the hypoglycemic and antioxidative effects of fermented paste (doenjang) prepared from soybean and brown rice mixed with rice bran or red ginseng marc in mice fed with high fat diet. Nutrients 6: 4610-4624, 2014

80. Wu D, Zheng N, Qi K, Cheng H, Sun Z, Gao B, Zhang Y, Pang W, Huangfu C, Ji S, et al: Exogenous hydrogen sulfide mitigates the fatty liver in obese mice through improving lipid metabolism and antioxidant potential. Med Gas Res 5: 1, 2015. 